\title{
FABRICAÇÃO DE CANALETAS EM SUBSTRATOS DE SILÍCIO PARA ACOPLAMENTO FIBRA-GUIA UTILIZANDO SILICETO DE NÍQUEL COMO MATERIAL DE MÁSCARA
}

Dissertação apresentada à Escola Politécnica

da Universidade de São Paulo para a obtenção do título de Mestre em Engenharia 


\title{
FABRICAÇÃO DE CANALETAS EM SUBSTRATOS DE SILÍCIO PARA ACOPLAMENTO FIBRA-GUIA UTILIZANDO SILICETO DE NÍQUEL COMO MATERIAL DE MÁSCARA
}

\author{
Dissertação apresentada à Escola Politécnica \\ da Universidade de São Paulo para a obtenção \\ do título de Mestre em Engenharia \\ Área de concentração: \\ Engenharia Elétrica
}

Orientador: Prof. Dr. Nilton Itiro Morimoto

São Paulo

2007 
Este exemplar foi revisado e alterado em relação à versão original, sob responsabilidade única do autor e com anuência de seu orientador.

São Paulo, 7 de dezembro de 2007.

Assinatura do autor:

Assinatura do orientador:

Mascaro, Amanda Rossi

Estudo de um filme de siliceto de níquel para ser utilizado como material de máscara em soluções alcalinas para aplicações em óptica integrada. São Paulo, 2007. 72p., Edição revisada.

Dissertação (Mestrado) - Escola Politécnica da Universidade de São Paulo, Departamento de Engenharia Eletrônica.

Orientador: Prof. Dr. Nilton Itiro Morimoto.

1. Óptica Integrada - acoplamento óptico. 2. Microeletrônica - processos em microeletrônica. Universidade de São Paulo. Escola Politécnica. Departamento de Engenharia Eletrônica II. Título. 
Dedico este trabalho aos meus pais, Maria Luiza Rossi Mascaro e Fernando de Morais Mascaro (in memorian), pelo incentivo incondicional à minha formação profissional. 


\section{Agradecimentos}

Ao professor Nilton Itiro Morimoto pela orientação, apoio e confiança demonstrada ao longo do trabalho.

Ao Dr. Luiz Carlos Donizetti Gonçalves pela ajuda sempre presente, contribuindo diretamente para a elaboração deste trabalho.

Ao Laboratório de Sistemas Integráveis da Escola Politécnica de São Paulo pela infraestrutura disponibilizada ao longo do trabalho.

Aos amigos do grupo LSI-EPUSP, LME-EPUSP e CCS-UNICAMP pela colaboração, atenção e solidariedade dispensadas durante a elaboração do trabalho.

Ao CNPq pelo apoio financeiro por um período desta pesquisa.

À minha mãe pelo desprendimento financeiro e de tempo permitindo que eu tivesse formação técnica e pessoal para aproveitar essa oportunidade, além do incentivo constante para alcançar esse objetivo.

A todas as pessoas que colaboraram para a realização, seja com um sorriso, uma palavra de ânimo, ou um olhar, seja voluntariamente ou não, deixo aqui o meu agradecimento. 


\section{Resumo}

Neste trabalho, apresentamos um novo processo de fabricação para a obtenção de canaletas em V em substratos de silício monocristalino (100) para um acoplamento óptico utilizando siliceto de níquel como material de máscara. O filme de siliceto de níquel $(10 \mathrm{~nm}$ de espessura para $200 \mathrm{~nm}$ de nickel) foi obtido por processos de evaporação térmica e posterior recozimento a baixas temperaturas $\left(200\right.$ e $250^{\circ} \mathrm{C}$ ). As canaletas em V (com profundidade de $60 \mu \mathrm{m}$ ) foram fabricadas através do processo de corrosão anisotrópica, utilizando uma solução de KOH (27\%$60^{\circ} \mathrm{C}$ ). Durante este processo, a taxa de corrosão do substrato de silício pela solução de $\mathrm{KOH}$ foi estimada como sendo $33.1 \mu \mathrm{m} / \mathrm{h}$. A composição da camada de siliceto de níquel obtida foi investigada utilizando a técnica RBS, que nos forneceu a estequiometria $\mathrm{Ni}_{2} \mathrm{Si}$. A rugosidade de filmes de níquel e de $\mathrm{Ni}_{2} \mathrm{Si}$ foi medida pela técnica AFM. Uma análise SEM foi feita com as canaletas e guias de onda obtidos. Após o processamento das canaletas em V, elas foram alinhadas com um guia de onda simples de teste para um futuro acoplamento óptico. 


\begin{abstract}
In this work, we present a new fabrication process to obtain V-grooves on monocrystaline silicon substrates (100) for optical coupling using nickel silicides as mask material. The nickel silicide film $10 \mathrm{~nm}$ thick for $200 \mathrm{~nm}$ of nickel thick) was obtained using thermal evaporation and annealing processes at low temperatures $\left(200\right.$ and $\left.250^{\circ} \mathrm{C}\right)$ as mask for alkaline solutions. Vgrooves $\left(60 \mu \mathrm{m}\right.$ deep) were fabricated by anisotropic etching process, using a $\mathrm{KOH}\left(27 \%-60^{\circ}\right)$ solution. During this process, the etch rate of the silicon substrate by the $\mathrm{KOH}$ solution was measured as $33.1 \mu \mathrm{m} / \mathrm{h}$. The composition of the obtained nickel silicide layer was investigated using RBS technique, which supplied us the stoichiometric $\mathrm{Ni}_{2} \mathrm{Si}$. The roughness of nickel and $\mathrm{Ni}_{2} \mathrm{Si}$ layers was measured by AFM technique. A SEM analysis was made with the obtained $V$ grooves and waveguides..

After processing the $\mathrm{V}$-grooves, they were aligned with a simple waveguide for a future optical coupling.
\end{abstract}




\section{Lista de figuras}

Figura 1: Vista da conexão por endfire para acoplamento entre fibra e o guia óptico................... 5

Figura 2: Teste da viabilidade do níquel para ser aplicado como material de máscara. Morfologia da camada de níquel sobre o substrato de silício após a corrosão em $\mathrm{KOH}$......................... 12

Figura 3: Substrato de silício após a remoção do filme de níquel........................................... 13

Figura 4: Análise morfológica das amostras sinterizadas a 200 e $250^{\circ} \mathrm{C}$ após o processo de corrosão em $\mathrm{KOH}$. A) amostra sinterizada a $200^{\circ} \mathrm{C}$ antes da remoção de níquel, B) amostra sinterizada a $200^{\circ} \mathrm{C}$ após a remoção de níquel, C) amostra sinterizada a $250^{\circ} \mathrm{C}$ antes da remoção de níquel e D) amostra sinterizada a $250^{\circ} \mathrm{C}$ após a remoção de níquel.

Figura 5: Pontos de penetração da solução de $\mathrm{KOH}$ para dentro do substrato de silício (direção 100), após o término do processo de corrosão.

Figura 6: Medidas de topografia. A) topografia da camada de níquel antes do tratamento térmico e B) topografia da camada de níquel após a formação do filme de $\mathrm{Ni}_{2} \mathrm{Si}$.

Figura 7: Análise RBS da formação da camada de $\mathrm{Ni}_{2} \mathrm{Si}$. O programa de simulação forneceu uma estequiometria de $2: 1$.

Figura 8: Máscara projetada para a realização do processo litográfico. Padrões de linhas utilizados para a obtenção de canaletas de acomodação de fibras ópticas.

Figura 9: Canaletas com largura de $70 \mu \mathrm{m}$ corroídas após 1,5 hora de corrosão a uma temperatura de $200^{\circ} \mathrm{C}$, por 20 minutos. A) vista superior das canaletas antes da remoção do níquel, B) vista superior das canaletas após remoção do níquel e C) vista das canaletas em seção transversal.

Figura 10: Canaletas com largura de $70 \mu \mathrm{m}$ corroídas após 2 horas de corrosão a uma temperatura de $200^{\circ} \mathrm{C}$, por 20 minutos. A) vista superior das canaletas antes da remoção do níquel, B) vista superior das canaletas após a remoção do níquel e C) vista das canaletas em seção transversal.

Figura 11: Canaletas com largura de $70 \mu \mathrm{m}$ corroídas após 1,5 hora de corrosão a uma temperatura de $250^{\circ} \mathrm{C}$, por 20 minutos. A) vista superior das canaletas antes da remoção do $\mathrm{Ni}_{2} \mathrm{Si}, \mathrm{B}$ ) vista superior das canaletas após a remoção do $\mathrm{Ni}_{2} \mathrm{Si}$ e C) vista das canaletas em seção transversal. 
Figura 12: Canaletas com largura de $70 \mu \mathrm{m}$ corroídas após 2 horas de corrosão a uma temperatura de $250^{\circ} \mathrm{C}$, por 20 minutos. A) vista superior das canaletas antes da remoção do $\mathrm{Ni}_{2} \mathrm{Si}, \mathrm{B}$ ) vista superior das canaletas após a remoção do $\mathrm{Ni}_{2} \mathrm{Si}$ e C) vista das canaletas em seção transversal.

Figura 13: Imperfeições no plano (111) do silício . A)região demarcada como referência e B) ampliação de (A) para melhor visualização de tais imperfeições. 25

Figura 14: Análise SEM para as canaletas obtidos após 2 horas de corrosão, utilizando-se temperaturas de sinterização de $250^{\circ} \mathrm{C}$. 26

Figura 15: Imagem SEM mostrando um grupo de canaletas corroídas................................... 26

Figura 16: imagem SEM de um guia planar obtido com largura de $4 \mu \mathrm{m}$ e altura de $5 \mu \mathrm{m} . . . . . . . .29$

Figura 17: Etapas de processo para a fabricação de uma estrutura de teste contendo guias de onda e canaletas alinhados entre si.

Figura 18: Conjunto contendo tanto as canaletas de acomodação de fibras ópticas quanto os guias de onda, alinhados entre si.

Figura 19: Ampliação contendo um conjunto de guias de onda e canaletas obtidas. 32

Figura 20: Indicação do corte de serra (vista de cima) para aproximação da fibra . 34

Figura 21: Rede cristalina do silício. 43

Figura 22: Perfis de corrosão anisotrópica para silício $<100>$. 44

Figura 23: Perfil de corrosão isotrópico. 45

Figura 24: Oxidação térmica do silício. 47

Figura 25: Guia de onda planar [35]. 54

Figura 26: Configurações com o campo elétrico transversal (TE) e magnético transversal (TM).55

Figura 27: Diagrama do vetor de onda [4]. 57

Figura 28: Distribuição do campo elétrico transversal para vários ângulos de incidência [4]...... 58

Figura 29: Solução gráfica da Equação 39, mostrando quatro valores de $\kappa$ permitidos [4]. 59 


\section{Lista de tabelas}

Tabela 1: Parâmetros de processo para a obtenção do filme de $\mathrm{SiO}_{2}$ térmico............................27

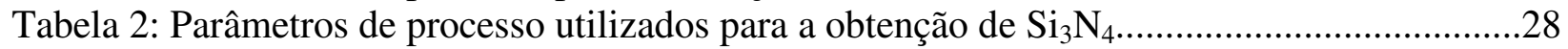

Tabela 3: Vantagens, desvantagens e aplicações de reatores CVD.........................................40

Tabela 4: Vantagens, desvantagens e aplicações de reatores PVD..........................................41

Tabela 5: Parâmetros do modelamento de Arrhenius..............................................................49 


\section{Lista de símbolos}

\begin{tabular}{|c|c|}
\hline $\mathrm{R}(100)$ & Taxa de corrosão do silício no plano $(100)[\mu \mathrm{m} / \mathrm{h}]$ \\
\hline $\mathrm{R}(111)$ & Taxa de corrosão do silício no plano $(111)[\mu \mathrm{m} / \mathrm{h}]$ \\
\hline $\mathrm{h}$ & Profundidade corroída $[\mu \mathrm{m}]$ \\
\hline h' & Corrosão lateral do silício $[\mu \mathrm{m}]$ \\
\hline$\theta$ & Ângulo formado no encontro dos planos (100) e (111) do silício $\left[{ }^{\circ}\right]$ \\
\hline $\mathrm{n}_{\mathrm{s}}$ & Índice de refração da camada superior \\
\hline $\mathrm{n}_{\mathrm{c}}$ & Índice de refração da camada central \\
\hline $\mathrm{n}_{\mathrm{su}}$ & Índice de refração do substrato \\
\hline$\vec{E}$ & Amplitude do campo elétrico [V/m] \\
\hline$\vec{H}$ & Amplitude do campo magnético $[\mathrm{A} / \mathrm{m}]$ \\
\hline$\vec{D}$ & Densidade do fluxo elétrico $\left[\mathrm{C} / \mathrm{m}^{2}\right]$ \\
\hline$\vec{B}$ & Densidade do fluxo magnético $\left[\mathrm{Wb} / \mathrm{m}^{2}\right]$ \\
\hline$\vec{J}$ & Densidade da corrente $\left[\mathrm{A} / \mathrm{m}^{2}\right]$ \\
\hline$\rho$ & Densidade de carga $\left[\mathrm{C} / \mathrm{m}^{3}\right]$ \\
\hline $\mathrm{Q}$ & Carga $[\mathrm{C}]$ \\
\hline$\theta_{\mathrm{c}}$ & Ângulo crítico para a interface superior $\left[{ }^{\circ}\right]$ \\
\hline$\theta_{\mathrm{s}}$ & Ângulo crítico para a interface inferior $\left[{ }^{\circ}\right]$ \\
\hline$\vec{P}$ & Polarização elétrica \\
\hline$\varepsilon_{0}$ & Permitividade elétrica no vácuo $[\mathrm{F} / \mathrm{m}]$ \\
\hline$\varepsilon$ & Permitividade elétrica no meio $[\mathrm{F} / \mathrm{m}]$ \\
\hline$\vec{M}$ & Polarização magnética \\
\hline$\vec{k}$ & Vetor de onda $[\mathrm{rad} / \mathrm{m}]$ \\
\hline$\omega$ & Freqüência angular [rad/s] \\
\hline$\vec{r}$ & Vetor posição \\
\hline$\lambda$ & Comprimento de onda $[\mathrm{nm}]$ \\
\hline $\mathrm{n}$ & Índice de refração de um meio \\
\hline $\mathrm{c}$ & Velocidade da luz no vácuo $[\mathrm{m} / \mathrm{s}]$ \\
\hline$V_{p}$ & Velocidade da luz no meio $[\mathrm{m} / \mathrm{s}]$ \\
\hline$\theta_{\mathrm{i}}$ & Ângulo incidente $\left[{ }^{\circ}\right]$ \\
\hline$\beta_{\mathrm{i}}$ & Coeficiente de propagação ao longo da direção z \\
\hline$\beta$ & Coeficiente de propagação \\
\hline$\kappa$ & Vetor de onda transversal \\
\hline $\mathrm{f}$ & Espessura da camada de guiamento $[\mu \mathrm{m}]$ \\
\hline$\gamma$ & Coeficiente de atenuação \\
\hline$\mu$ & Permeabilidade magnética $[\mathrm{H} / \mathrm{m}]$ \\
\hline$\mu_{\mathrm{o}}$ & Permeabilidade magnética no vácuo $[\mathrm{H} / \mathrm{m}]$ \\
\hline
\end{tabular}




\section{Lista de abreviaturas}

$\begin{array}{ll}\text { AFM } & \text { Atomic Force Microscopy } \\ \text { APCVD } & \text { Atmospheric Pressure Chemical Vapor Deposition } \\ \text { ARROW } & \text { Anti-Resonant Reflecting Optical Waveguides } \\ \text { BOE } & \text { Buffered Oxide Etching } \\ \text { CVD } & \text { Chemical Vapor Deposition } \\ \text { LPCVD } & \text { Low Pressure Chemical Vapor Deposition } \\ \text { MOCVD } & \text { Metal Organic Chemical Vapor Deposition } \\ \text { MOEMS } & \text { Micro -Opto Eletromechanical Systems } \\ \text { PVD } & \text { Physical Vapor Deposition } \\ \text { PECVD } & \text { Plasma Enhanced Chemical Vapor Deposition } \\ \text { RBS } & \text { Rutherford Backscattering } \\ \text { RCA } & \text { Radio Corporation of America } \\ \text { RIE } & \text { Reactive Ion Etching } \\ \text { SEM } & \text { Scanning Electron Microscope }\end{array}$




\section{Sumário}

Resumo

Lista de figuras

Lista de tabelas

Lista de símbolos

Lista de abreviaturas

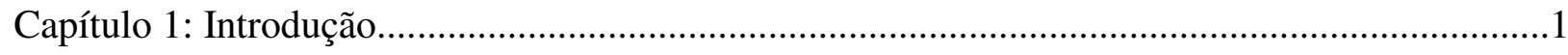

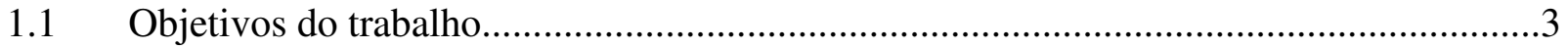

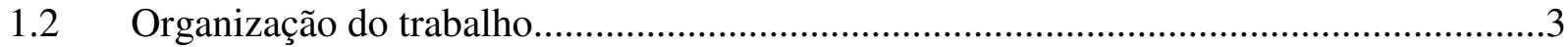

Capítulo 2: Metodologia utilizada para a fabricação das canaletas.............................................5

2.1 A escolha da técnica de acoplamento entre fibra óptica e guia de onda.......................5

2.2 Processamento de substratos de silício para a formação de canaletas de acomodação de fibras ópticas....................................................................................................

2.3 A escolha das etapas de processo e do material da máscara para a fabricação das

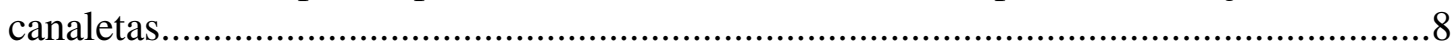

Capítulo 3: Estudo de filmes de níquel e silicetos de níquel como material de máscara para

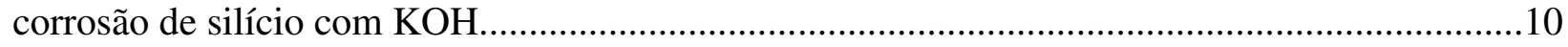

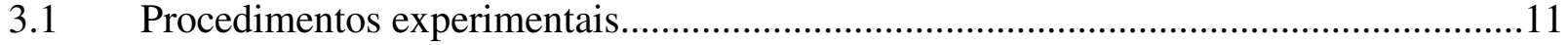

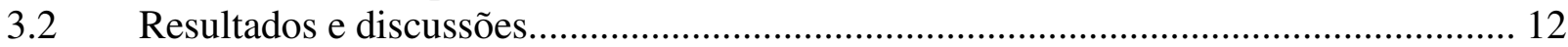

Capítulo 4: Processos de fabricação de canaletas e guias de onda.............................................. 18

4.1 Processos de fabricação de canaletas: procedimentos experimentais.......................... 18

4.2 Processos de fabricação de canaletas: resultados e discussões................................... 19

4.3 Processos de fabricação de guias de onda: procedimentos experimentais................... 26

4.4 Processos de fabricação de guias de onda: resultados e discussões............................. 29

4.5 Fabricação de uma estrutura ilustrativa contendo canaletas e guias de onda alinhados:

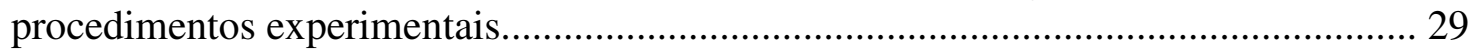

4.6 Fabricação de uma estrutura ilustrativa contendo canaletas e guias de onda alinhados:

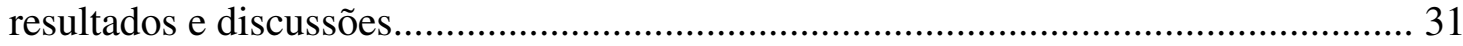

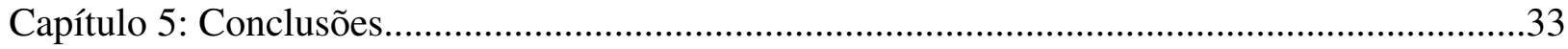

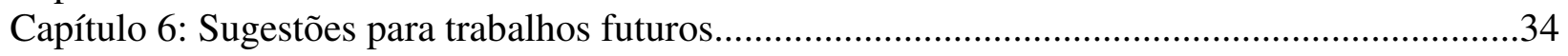

Referências Bibliográficas............................................................................................... 32

Apêndice A: Etapas de processo em microeletrônica e técnicas de análise de materiais..............39

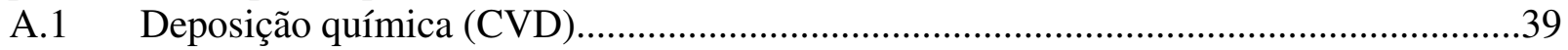

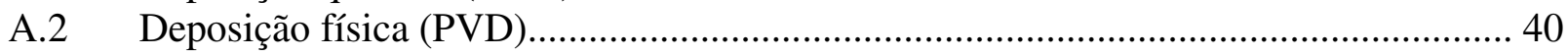

A.3 Técnicas de corrosão............................................................................................4

A.3.1 Corrosão anisotrópica em substratos de silício.......................................................42

A.3.2 Corrosão isotrópica em substratos de silício................................................................ 44

A.3.3 Corrosão por plasma em substratos de silício...........................................................46

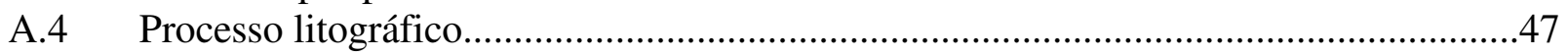

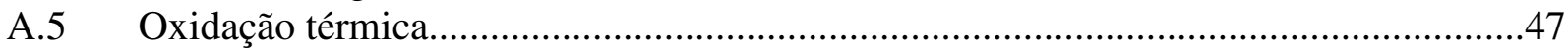

A .6 Modelamento de Arrhenius..............................................................................49

Apêndice B: equações básicas para o guiamento óptico planar..................................................50

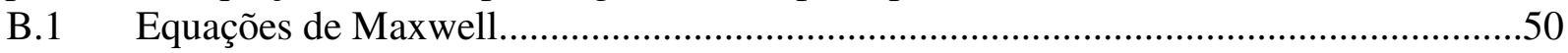

B.2 Relações construtivas........................................................................................52

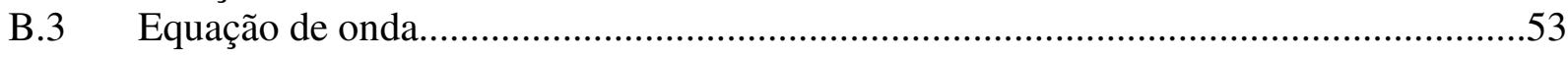




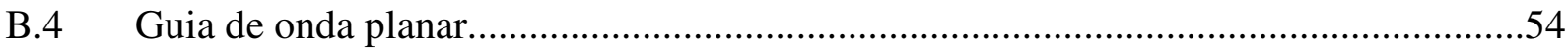

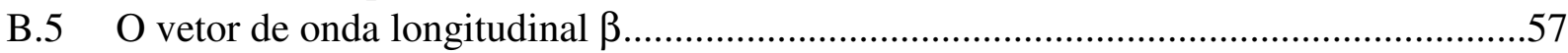

B.6 Equação característica dos modos...................................................................58 


\section{Capítulo 1: Introdução}

Nas últimas décadas houve um crescente avanço tecnológico em óptica integrada, que foi motivado pela necessidade da comunicação e condicionamento de dados enviados por fibras ópticas. O processamento de sinais ópticos está associado, por sua vez, à pesquisa e ao desenvolvimento de novos dispositivos e sensores híbridos micro-opto-eletro-mecânicos (MOEMS) [1].

A tecnologia MOEMS tem como um dos principais objetivos a adaptação em menor escala de estruturas já desenvolvidas e consagradas em escala macroscópica. Estruturas ópticas como acopladores bidirecionais, divisores de intensidade, interferômetros, moduladores eletroópticos de fase e de amplitude de precisão, são exemplos dessas estruturas. Como vantagens dos circuitos ópticos integrados podemos citar a facilidade do controle de temperatura e a estabilidade mecânica, além da redução da carga útil e das dimensões dos dispositivos [2].

Os dispositivos ópticos integrados podem ser fabricados sobre substratos diversos, por exemplo, sobre Si [3], $\mathrm{LiNbO}_{3}$ [4], ou mesmo sobre vidro. Diversas técnicas são empregadas para a fabricação de tais dispositivos: deposição por decomposição pirolítica de vapores orgânicos (LPCVD) ou assistida por plasma (PECVD), crescimento epitaxial por vapor químico (MOCVD) e difusão iônica. Independentemente do processo de fabricação do dispositivo, em geral, é necessário que o mesmo seja conectado ao mundo externo através de ligações ópticas ou elétricas. As ligações elétricas podem ser utilizadas para efetuar a transdução do sinal opticamente condicionado a uma estrutura elétrica fabricada na própria pastilha. Suas aplicações são importantes em sistemas MOEMS e óptica integrada para permitir o controle e análise de sinais ópticos [4]. As comunicações ópticas e os sensores eletroópticos de precisão necessitam de guias ópticos e de componentes tais como moduladores de fase e de amplitude e estes são objetos de estudo e desenvolvimento para as áreas de sensores em geral, telecomunicações, computação óptica e área médica.

A conexão dos componentes ópticos com o exterior da pastilha pode ser feita também através de fibras ópticas. Faz-se necessário então o suporte mecânico das fibras ópticas conectorizadas. A metodologia mais simples para esta conexão é o acoplamento do tipo endfire. Neste caso, padrões de corrosão em V ou em U são fabricados em um substrato, em particular na própria pastilha ou 
aderidos ao substrato onde foram fabricados os dispositivos ópticos. As canaletas, que acomodam tanto a fibra de lançamento como a de coleta de luz, tem a sua geometria especialmente confeccionada para o perfeito posicionamento da fibra em relação às camadas opticamente ativas do guia integrado. Esse posicionamento é feito de modo a haver a maior sobreposição (overlap) possível dos modos, o que em geral implica numa maior transferência de potência óptica entre fibra e guia [5].

Os perfis de corrosão que acomodam a fibra óptica, em V ou U, são obtidos através de processos físico-químicos, sejam baseados em plasma ou no ataque químico das superfícies dos substratos selecionadas por máscaras adequadas. Os perfis em V são mais convenientes de serem obtidos para vários substratos monocristalinos como o silício, em particular, por soluções alcalinas que tem como característica taxas de corrosão distintas conforme a particular direção cristalina [6]. Esse tipo de corrosão anisotrópica é padrão para a definição das canaletas que acomodam fibras ópticas em substratos de silício, sendo que a relação entre as taxas de corrosão nas direções (100) e (111) está na faixa de 30:1 para soluções de $\mathrm{KOH}$ a 30\% [7], propiciando assim um controle bastante preciso da altura da fibra em relação ao guia de onda integrado.

A microfabricação das canaletas em $\mathrm{V}$ em soluções alcalinas exige que o material escolhido para o papel de máscara seja quimicamente resistente para suportar o tempo de corrosão de profundidades na ordem do raio de uma fibra óptica e mesmo de até $2 / 3$ da espessura de uma pastilha de silício para a fabricação de membranas. Tradicionalmente, os materiais que são mais utilizados como máscara são o $\mathrm{SiO}_{2}$ e o $\mathrm{Si}_{3} \mathrm{~N}_{4}$. Porém, estes materiais apresentam algumas limitações [8], que serão discutidas ao longo do trabalho.

Uma alternativa às máscaras de ou $\mathrm{Si}_{3} \mathrm{~N}_{4}$ seria um material resistente à soluções alcalinas. Apesar do níquel ser conhecido pela sua baixa adesão ao silício [9], esse material foi empregado com sucesso como máscara para corrosão química alcalina de silício na sua forma de siliceto [10]. Além da deposição de níquel simplificar o processo por nós proposto, ele possui boa seletividade na corrosão química desse metal em relação a oxinitretos [11], camadas componentes de dispositivos ópticos práticos [12]. Além de resistente a meios alcalinos, o siliceto de níquel pode ser submetido a processos RIE de alta densidade em etapas posteriores à corrosão química, como máscara para a fabricação de trincheiras na entrada e na saída dos guias ópticos. 


\subsection{Objetivos do trabalho}

O presente trabalho tem como principal objetivo o desenvolvimento de um processo que possibilite a confecção de canaletas para acomodação de fibras ópticas, utilizando $\mathrm{Ni}_{2} \mathrm{Si}$ como material de máscara e processos de corrosão anisotrópica profunda. Essas canaletas serão alinhadas a um guia de onda óptico de teste através de um conjunto de máscaras projetado pelo Dr. Luiz Carlos Donizetti Gonçalves (PEA-EPUSP) para um futuro acoplamento óptico. Os filmes que serão fabricados para o componente óptico de teste, um simples guia de onda, serão feitos a baixas temperaturas por processos de plasma.

Os processos desenvolvidos para efetuar a interface entre os guias e fibras serão processos comuns de microeletrônica. Em particular, o material que servirá de máscara sobre o silício, o níquel na sua fase $\mathrm{Ni}_{2} \mathrm{Si}$, será obtido através de um simples processo de evaporação térmica com o posterior tratamento térmico a baixas temperaturas $\left(250^{\circ} \mathrm{C}\right)$.

Um ponto de destaque do presente trabalho talvez seja a simplicidade geral dos processos escolhidos e a sua adequação a processamentos em baixas temperaturas do substrato e camadas depositadas.

\subsection{Organização do trabalho}

Este trabalho foi elaborado estruturando-se em 6 capítulos sendo que este corresponde ao capítulo 1, onde descrevemos sucintamente a motivação e os objetivos do trabalho.

No Capítulo 2 apresentamos a metodologia utilizada para a escolha das etapas de processo do trabalho e dos materiais utilizados.

No Capítulo 3 apresentamos os procedimentos experimentais, resultados e discussões referentes ao estudo de filmes finos de níquel e silicetos de níquel para serem utilizados como material de máscara para corrosão com $\mathrm{KOH}$.

No Capítulo 4 apresentamos os procedimentos experimentais, resultados e discussões referentes a fabricação de canaletas e guias de onda utilizando $\mathrm{Ni}_{2} \mathrm{Si}$ como máscara, concomitantemente com a fabricação de uma estrutura ilustrativa contendo canaletas e guias de onda alinhados entre si para um futuro acoplamento óptico por endfire.

No Capítulo 5 apresentamos as conclusões dos estudos realizados. 
No Capítulo 6, apresentamos sugestões para trabalhos futuros 


\section{Capítulo 2: Metodologia utilizada para a fabricação das canaletas}

Neste capítulo, descreveremos a metodologia utilizada no trabalho, passando pela escolha do tipo de técnica de acoplamento utilizada, dos tipos de processamento utilizados e do material que será utilizado como máscara.

\subsection{A escolha da técnica de acoplamento entre fibra óptica e guia de onda}

Atualmente, existem vários tipos de acoplamentos ópticos que podem ser implementados. Podemos citar o acoplamento por prisma [13], por rede de Bragg [14] e por endfire [3]. O acoplamento por prisma, baseado na reflexão interna na camada ativa do guia, possui uma alta eficiência [13].

Todas as estruturas utilizadas para o acoplamento entre fibras e guias possuem vantagens e desvantagens, associadas tanto aos mecanismos de perdas envolvidos quanto às dificuldades inerentes ao seu processo de fabricação. As estruturas que utilizam redes de Bragg ou prismas no seu processo de fabricação, por exemplo, possuem como qualidade única a sua capacidade de selecionar uma faixa de comprimentos de onda bem estreita. Porém, é de nosso conhecimento que tantoo acoplamento por prisma necessita de um projeto complexo: o posicionamento da fibra em relação ao guia é feito por estruturas de suporte não integráveis, além de que o posicionamento em ângulo requer diferentes projetos para cada comprimento de onda utilizado [14]. Nos acoplamentos tipo endfire, a face da fibra é posta paralela à face do guia, como mostra a Figura 1:

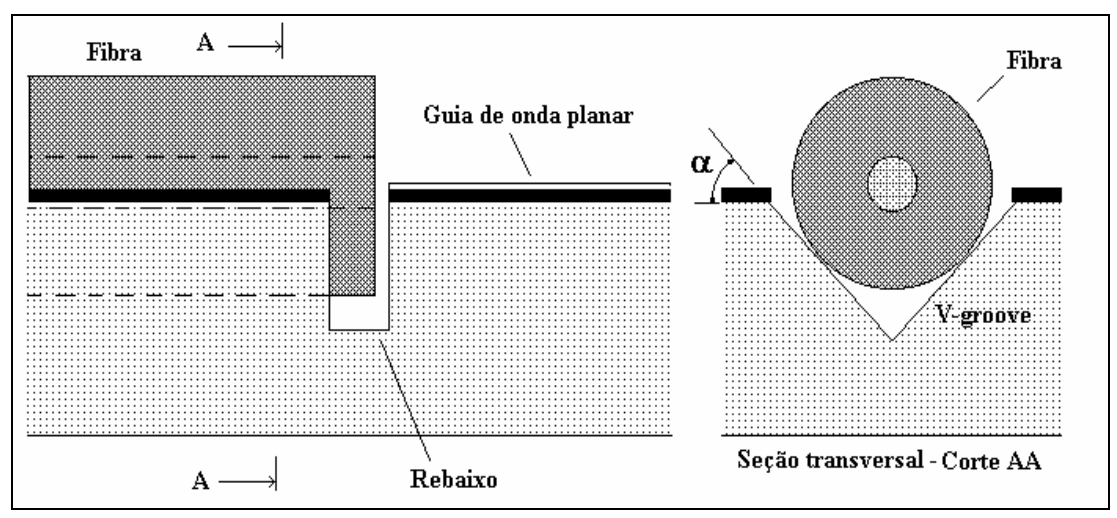

Figura 1: Vista da conexão por endfire para acoplamento entre fibra e o guia óptico. 
Os mecanismos de perda estão essencialmente associados a maior ou a menor sobreposição (overlap) possível dos modos, o que em geral implica numa maior transferência de energia radiante entre fibra e guia. A limitação na transferência de potência pode ser compensada, no caso de modos com diferentes perfis, através da fabricação de lentes na entrada do guia ou na saída da fibra ou através de camadas refletoras associadas (como é o caso dos guias ARROW).

Embora a maioria dos acoplamentos por endfire possua uma baixa eficiência, é possível utilizar técnicas de modificação do dispositivo para sanar este problema, como fizeram LLobera et al [15]. Nessa referência, além de uma estrutura $A R R O W$ associada ao dispositivo, utilizando lentes antirefletoras depositadas por processos convencionais em microeletrônica, a eficiência de acoplamento foi maximizada pela construção de um guia monomodo onde os modos foram casados geometricamente (mesma distribuição de perfil modal). Além disso, o guia foi fabricado de modo que tanto o índice efetivo da fibra como o do modo guia de onda integrado estivessem casados em aproximadamente 1,46 .

A grande vantagem do acoplamento endfire é a sua simplicidade e este tipo de acoplamento possibilita inclusive a inserção de luz branca nos dispositivos. Porém, devido a limitação imposta pelo seu projeto simples, a eficiência de acoplamento pode ser baixa. Devido ao descasamento dos modos da fibra com os modos do guia de onda durante a etapa de alinhamento, alguns artigos na literatura relatam a obtenção de até $10 \%$ de eficiência [3], devendo sofrer as alterações anteriormente citadas para o ajuste do dispositivo [15].

Alguns ajustes citados na literatura consideram ainda a deposição de uma camada antirefletora de filme fino na fibra óptica para diminuir as perdas por diferenças de índices entre o guia e a fibra. Num caso mais dramático, por exemplo, no acoplamento entre fibras e guias de onda fabricados em $\mathrm{LiNbO}_{3}$, os autores da ref. [4] puderam aumentar a eficiência do acoplamento utilizando essa técnica.

O alinhamento, presente em todos os processos de acoplamento, pode ser considerado uma questão crítica devido à sua ligação direta com a perda por inserção e problemas na interface fibra-guia, como reflexões de Fresnel, por exemplo.[4]. Entretanto, num primeiro momento, resolvemos que a estrutura que reunia a maior simplicidade seria aquela de conexões do tipo endfire [1]. 


\subsection{Processamento de substratos de silício para a formação de canaletas de acomodação de fibras ópticas}

O processamento de estruturas ópticas, tendo em vista a sua conexão, conta com diversos trabalhos na literatura. Mayer [16] patenteou um método de obtenção de componentes ópticos poliméricos, tendo a conexão entre as fibras e os guias de onda posicionada em canaletas com a forma geométrica de $\mathrm{V}$, reproduzidas a partir de uma canaleta construída em silício.

Heideman et al [8] propuseram um método de conexão entre fibra óptica e guia de onda através de estruturas em $\mathrm{V}$ feitas em substratos de silício por corrosão química com uma solução contendo $\mathrm{KOH}$. O processo foi essencialmente subdividido em uma etapa de fabricação das canaletas de acomodação da fibra, a posterior fabricação do guia de onda e, finalmente, uma etapa de polimento. Posteriormente, a fibra foi conectada ao guia de onda utilizando-se uma cola transparente utilizada em faixas de espectros UV com índice de refração 1.5. A eficiência de acoplamento obtida variou entre 0,1 e $1 \%$.

Para a obtenção dos perfis em $\mathrm{V}$ ou $\mathrm{U}$, o substrato é geralmente corroído por processos químicos em fase líquida ou gasosa. Processos baseados em plasma são freqüentemente utilizados também e são baseados tanto no ataque puramente iônico dos substratos pelas espécies dissociadas, como pelo ataque químico das superfícies. Os diferentes perfis, em particular os obtidos em substratos de silício, ocorrem devido às diferentes taxas de corrosão nas várias direções cristalinas [6]. O processamento necessário para a obtenção de tais canaletas utiliza a fabricação de padrões litográficos numa máscara previamente depositada ou crescida sobre o substrato.

Nessa máscara são abertas janelas que deixam exposto o substrato e perfis em U ou V são então obtidos submetendo-se essas aberturas à plasmas reativos ou à soluções corrosivas [3]. Em particular, substratos de Si (100), corroídos em soluções de $\mathrm{KOH}$ (30\% em peso [3]), apresentarão um perfil final em $\mathrm{V}$ nas regiões sem mascaramento, quando a abertura retangular for orientada na direção (110). Esse perfil em V é uma manifestação do caráter anisotrópico do processo de corrosão, que pode ser interpretado como consequiência dos diferentes mecanismos 
de transferência eletrônica nos vários pontos da zona de Brillouin [7]. A mesma estrutura, submetida a soluções ácidas, exibirá um formato em U, característico de taxas de corrosão independentes da orientação cristalográfica do silício. Isso ocorre, por exemplo, em soluções contendo $\mathrm{HNO}_{3}$ a $20^{\circ} \mathrm{C}$ [12]. Em plasmas reativos, com misturas de $\mathrm{SiF}_{6}$ ou $\mathrm{HF}$ [12] o substrato também apresenta taxas de corrosão iguais nas várias direções.

A corrosão anisotrópica é normalmente utilizada como solução para a definição das regiões das canaletas que acomodarão a fibra óptica em substratos de silício. Isso deve-se especialmente ao o controle de profundidade, que é obtido apenas pela largura da máscara empregada, já que a relação entre as taxas de corrosão nas direções (100) e (111) está na faixa de 30 para a soluções de $\mathrm{KOH}$ a $30 \%$ [7]. Essa relação entre taxas de corrosão propicia um controle bastante preciso da altura da fibra em relação ao guia de onda integrado.

\subsection{A escolha das etapas de processo e do material da máscara para a fabricação das canaletas}

O processo de corrosão úmida anisotrópica é utilizado como uma etapa de processo para a definição das canaletas $\mathrm{V}$ ou em $\mathrm{U}$, ou para a definição de membranas em substratos de silício. $\mathrm{O}$ acoplamento de dispositivos ópticos integrados com fibras exige uma etapa litográfica para a fabricação das canaletas, etapa esta que envolve a utilização de técnicas baseadas em corrosão por plasma ou por soluções químicas. As profundidades corroídas do substrato, nesses casos, são da ordem do raio de uma fibra óptica (aproximadamente $60 \mu \mathrm{m}$ ) ou da ordem de 2/3 da espessura de uma pastilha de silício para a fabricação de membranas, num dispositivo transdutor óptico típico. Em particular, guias de onda ópticos podem ser fabricados a partir de multicamadas de $\mathrm{SiO}_{\mathrm{x}} \mathrm{N}_{\mathrm{y}}$ depositadas sobre substratos de silício. Após o delineamento dos guias, na etapa litográfica que define a região das canaletas, as regiões de substrato expostas podem ser tanto corroídas por íons reativos (reactive ion etching - RIE) de plasmas de $\mathrm{SF}_{6} / \mathrm{Ar} / \mathrm{O}_{2}$ como por uma etapa química de $\mathrm{KOH}[12]$.

O processo de corrosão depende, portanto, da composição dos reagentes, temperatura e tempo de processo e, no caso de corrosão anisotrópica, da orientação cristalográfica da amostra. 
No caso da solução de escolha para a fabricação das canaletas, o $\mathrm{KOH}$, fotorresistes são removidos ou diluídos facilmente. Camadas de $\mathrm{SiO}_{2}$ crescidas termicamente, com espessuras de 2 2 m e bastante compactas [17], são utilizadas como máscara em processos de corrosão anisotrópica profundas, sendo consumido moderadamente quando entra em contato com uma solução contendo $\mathrm{KOH}$ [12]. Camadas de $\mathrm{Si}_{3} \mathrm{~N}_{4}$ não são consumidas em soluções com $\mathrm{KOH}$, porém apresentam um grau de estresse que pode comprometer a estrutura final.

Uma alternativa às máscaras de $\mathrm{SiO}_{2}$ ou $\mathrm{Si}_{3} \mathrm{~N}_{4}$ seria um material resistente à soluções alcalinas. Um material que apresenta essa característica e boa resistência estrutural tais características é o níquel na sua fase de siliceto, em particular a fase $\mathrm{Ni}_{2} \mathrm{Si}$.

Apesar do níquel ser conhecido pela sua baixa adesão ao silício [9], esse material foi empregado como máscara para corrosão química de silício [10] e outros materiais, como a safira e o GaN, na confecção de guias de onda e sensores. Tradicionalmente, a deposição de uma camada de cromo sobre o silício garante que o níquel não se descole. Porém, a presença do cromo exposto a soluções de $\mathrm{KOH}$ é indesejável, já que é consumido a uma taxa da mesma ordem daquela do $\mathrm{SiO}_{2}$ térmico [12], além de ser um metal pesado. A utilização de níquel na sua forma de siliceto dispensa o uso da camada de cromo. Além da deposição de níquel ser um processo mais simples e menos oneroso, o níquel apresentam boa seletividade na corrosão química em relação a oxinitretos, para a várias soluções existentes na literatura [12]. Para remover este filme, geralmente é utilizada uma solução de água régia diluída [12]. 


\section{Capítulo 3: Estudo de filmes de níquel e silicetos de níquel como material de máscara para corrosão de silício com KOH}

Neste capítulo, é feito um estudo da viabilidade da aplicação do níquel na sua forma de siliceto como material de máscara.

Os silicetos são comumente usados em processos de microeletrônica para reduzir a resistividade presente na porta e na metalização de transistores MOS em circuitos integrados. Nesse processo, utiliza-se geralmente o $\mathrm{TiSi}_{2}$ e $\mathrm{CoSi}_{2}$ [18]. Porém, estes silicetos apresentam algumas limitações. $\mathrm{O} \mathrm{TiSi}_{2}$ apresenta uma dependência da resistência de folha com a largura da linha para linhas com largura menor que $2 \mu \mathrm{m}$. Além disso, a mudança de fases de alta resistividade para baixa resistividade é limitada por nucleação e em linhas estreitas a densidade da nucleação não é alta o suficiente para assegurar a transformação total da fase. Já o $\mathrm{CoSi}_{2}$ não apresenta dependência da resistência de folha com a largura da linha, porém consome-se muito mais Si para a formação desta espécie do que para a formação de $\mathrm{TiSi}_{2}$ [18].

Com a utilização de silicetos de níquel, estes problemas podem ser evitados. A resistividade do $\mathrm{Ni}_{2} \mathrm{Si}$ e do NiSi está em torno de 24 e $14 \mu \Omega$.cm, respectivamente. Como o níquel é a espécie reagente durante a formação de $\mathrm{Ni}_{2} \mathrm{Si}$ e $\mathrm{NiSi}$, para a conversão de fases é necessário somente um processo de sinterização. Outras vantagens incluem a baixa temperatura de formação e o baixo consumo de $\mathrm{Si}$, e a não dependência da resistência de folha com a largura da linha, o que o torna viável para aplicações em dispositivos MOS [18]. Trabalhos recentes publicados por Mukai et al [19] demonstraram que é possível a obtenção de estruturas auto- alinhadas de silicetos de Ni com linhas de 0,2 a $16 \mu \mathrm{m}$.

Propriedades mecânicas como alta rigidez e resistência à meios alcalinos de corrosão torna este material um forte candidato para a utilização como material de proteção, passivação e promotor de aderência entre o silício e o níquel, por exemplo [20].

A cinética de crescimento de $\mathrm{Ni}_{2} \mathrm{Si}$ e NiSi está baseada em uma modelagem do tipo Arrhenius e está descrita no Apêndice A. Para faixas de temperatura que vão de 297 a $430^{\circ} \mathrm{C}$ duas fases se formam seqüencialmente: $\mathrm{Ni}_{2} \mathrm{Si}$ e $\mathrm{NiSi}$, respectivamente [21].

\subsection{Procedimentos experimentais}


As lâminas de silício utilizadas para os procedimentos experimentais foram lâminas de 3", com espessura de $280 \mu \mathrm{m}$, do tipo p, com orientação cristalográfica (100) e resistividade de 1020 ' '.cm. Antes de efetuar a fabricação das microestruturas, as lâminas foram limpas utilizandose o procedimento de limpeza conhecido como limpeza RCA. A limpeza SPM + HF + RCA é realizada em quatro passos, sendo que em cada passo são utilizadas soluções diferentes, como descritas a seguir:

10 passo: $\mathrm{H}_{2} \mathrm{SO}_{4}+\mathrm{H}_{2} \mathrm{O}_{2}$, numa proporção de 4:1 que é conhecida como solução piranha.

$\underline{\mathbf{2}^{\mathbf{o}} \text { passo: }} \mathrm{HF}+\mathrm{H}_{2} \mathrm{O}$ na proporção 1:10. Esta solução é utilizada para retirar o óxido nativo da lâmina.

3o passo: $\mathrm{NH}_{4} \mathrm{OH}+\mathrm{H}_{2} \mathrm{O}_{2}+\mathrm{H}_{2} \mathrm{O}$ na proporção 1:1:5. Esta solução é utilizada para remover partículas e dissolver compostos orgânicos.

$\underline{4^{0} \text { passo: }} \mathrm{HCl}+\mathrm{H}_{2} \mathrm{O}_{2}+\mathrm{H}_{2} \mathrm{O}$ na proporção 1:1:5. Esta solução tem a finalidade de retirar metais como $\mathrm{Cu}, \mathrm{Ag}, \mathrm{Zn}, \mathrm{Cd}$ e metais de transição.

Estas soluções foram colocadas em béqueres limpos e depois foram aquecidas a $80^{\circ} \mathrm{C}$ no hot plate, exceto no segundo passo, cuja limpeza foi realizada a temperatura ambiente. As lâminas foram mergulhadas por 10 minutos em cada solução. Antes de passar de uma solução para outra, as lâminas foi lavada em água D.I por 5 minutos. Ao fim da limpeza, as lâminas foram secas com nitrogênio e guardadas em recipiente limpo e apropriado para o transporte das lâminas. Após o processo de limpeza, uma camada de níquel foi depositada em todos os substratos.

A deposição de níquel pode ser efetuada com diferentes técnicas, entre elas a evaporação por feixe de elétrons (e-beam) ou térmica [22] e a deposição química passiva (electroless) [23]. Essas técnicas fornecem filmes com estruturas e composições distintas. O processo de deposição por evaporação térmica possui relativa simplicidade em relação a outros processos de deposição [24], permitindo a obtenção de filmes com uma boa uniformidade e cobertura de degrau. Além da simplicidade, a utilização de camadas sacrificiais de níquel obtidas em baixas temperaturas permite o processamento de substratos que não toleram processos de altas temperaturas, como o LPCVD.

A evaporação térmica foi feita em duas etapas consecutivas, evaporando-se em cada uma metade da massa total $(0.15 \mathrm{~g})$. Para o processo, utilizou-se um filamento de tungstênio.

A espessura de níquel obtida com este processo foi de $200 \mathrm{~nm}$. 
Terminado o processo de evaporação térmica, foi feito um teste da viabilidade de utilização do níquel como material de máscara para corrosão.

Para testar a viabilidade do níquel para ser utilizado como material de máscara para corrosão em uma solução contendo $\mathrm{KOH}\left(27 \%\right.$ a $\left.60^{\circ} \mathrm{C}\right)$, algumas amostras foram expostas à solução de corrosão durante o período de 1 hora imediatamente após o processo de evaporação térmica. $\mathrm{O}$ níquel foi então removido utilizando-se uma solução de água régia diluída $\left(3 \mathrm{HCl}+1 \mathrm{HNO}_{3}+2\right.$ $\left.\mathrm{H}_{2} \mathrm{O}\right)$.

Outras amostras foram levadas a um forno de sinterização a 200 e $250^{\circ} \mathrm{C}$ por um tempo de 20 minutos antes de serem submetidas à solução de $\mathrm{KOH}$. Após um processo de corrosão de 1 hora com a referida solução, uma microscopia foi feita antes e após a remoção da camada de níquel.

A rugosidade da camada de níquel foi medida pela técnica AFM [25] e a estequiometria após a sinterização foi medida pela técnica RBS [26]. Os resultados são discutidos na próxima seção.

\subsection{Resultados e discussões}

A Figura 2 mostra o substrato de silício contendo níquel obtido por evaporação térmica após a imersão pelo tempo de 1 hora na solução contendo $\mathrm{KOH}$ :

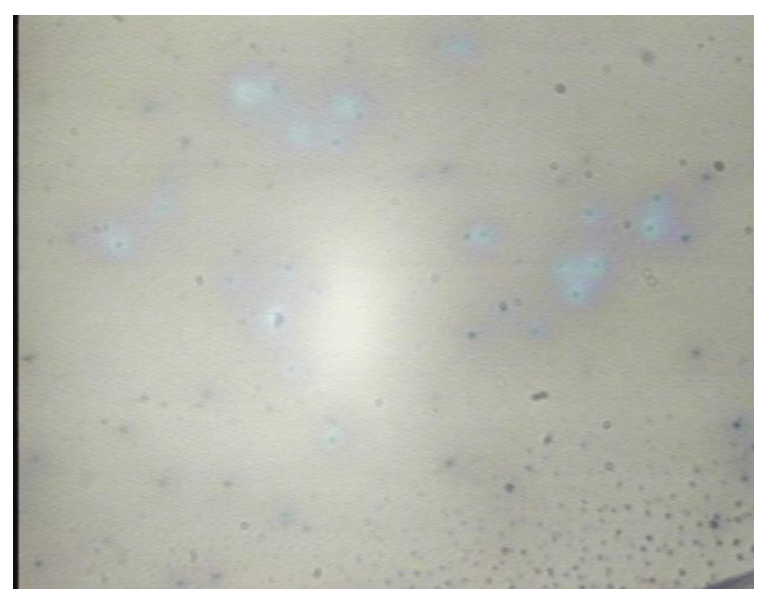

Figura 2: Teste da viabilidade do níquel para ser aplicado como material de máscara. Morfologia da camada de níquel sobre o substrato de silício após a corrosão em $\mathrm{KOH}$.

Na Figura 2, foi possível observar pequenas regiões azuladas ou escuras contrastando com o fundo amarelado do filme de níquel.

A Figura 3 mostra o substrato de silício após a remoção do filme de níquel: 


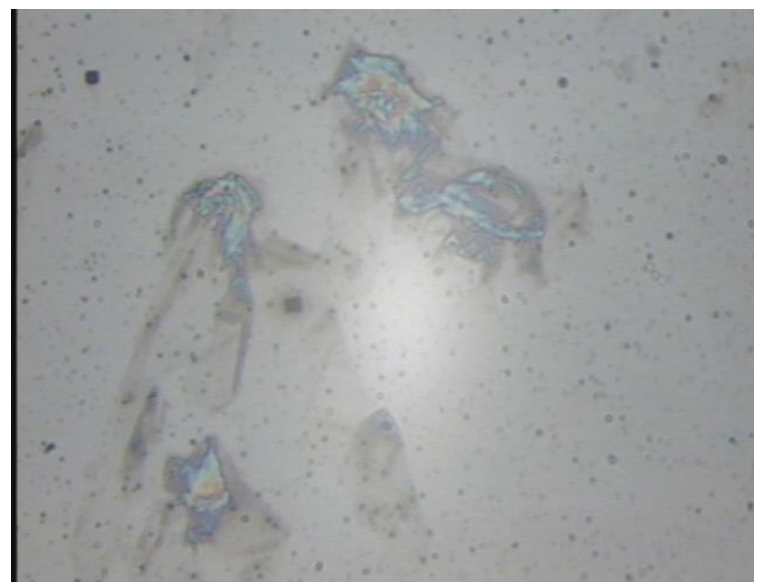

Figura 3: Substrato de silício após a remoção do filme de níquel.

Após a remoção do filme, constatamos que as regiões escuras observadas na Figura 2 representavam pontos de migração da solução de $\mathrm{KOH}$ para dentro do substrato de silício, como podemos ver na Figura 3.

A partir desses resultados verificamos que a simples evaporação térmica de níquel sobre silício não foi suficiente para garantir a adesão do níquel sobre o silício e a resistência à meios alcalinos.

Os resultados obtidos para amostras sinterizadas a 200 e $250^{\circ} \mathrm{C}$ após a imersão em $\mathrm{KOH}$ estão apresentados na Figura 4, que continua na página seguinte.

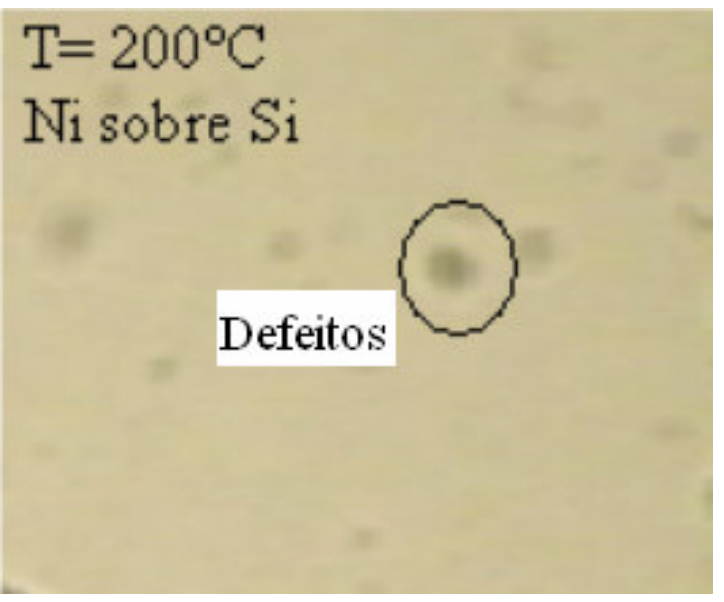

A)
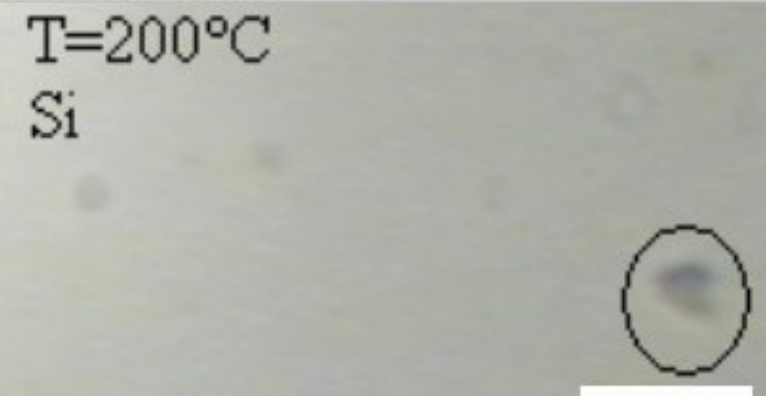

Defeitos
B) 


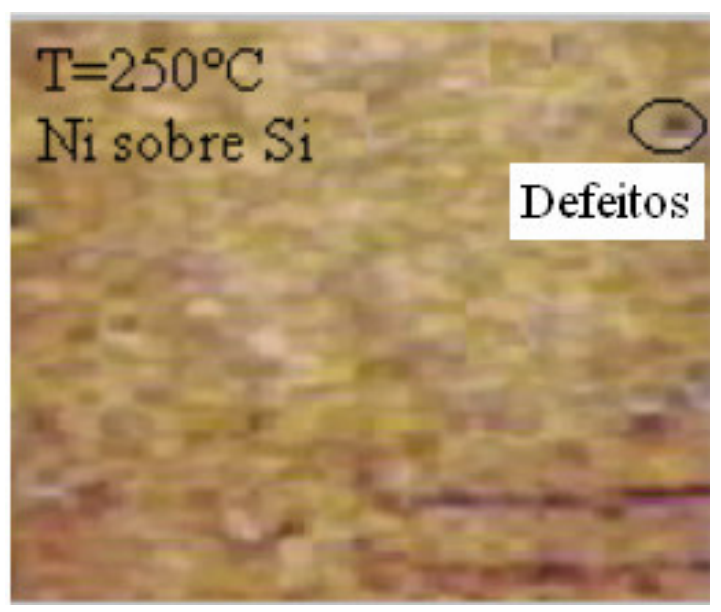

$\mathrm{C}$

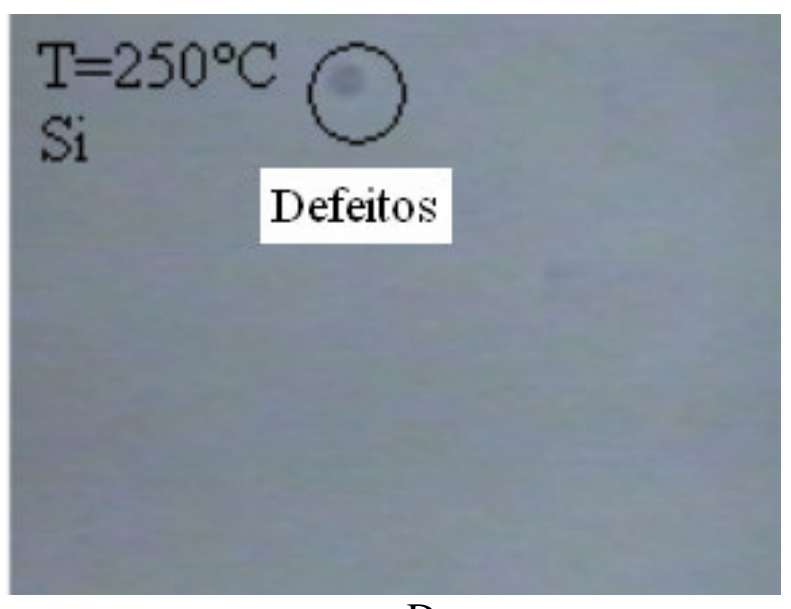

$\mathrm{D}$

Figura 4: Análise morfológica das amostras sinterizadas a 200 e $250^{\circ} \mathrm{C}$ após o processo de corrosão em $\mathrm{KOH}$. A) amostra sinterizada a $200^{\circ} \mathrm{C}$ antes da remoção de níquel, B) amostra sinterizada a $200^{\circ} \mathrm{C}$ após a remoção de níquel, C) amostra sinterizada a $250^{\circ} \mathrm{C}$ antes da remoção de níquel e D) amostra sinterizada a $250^{\circ} \mathrm{C}$ após a remoção de níquel.

A Figura 4 A) exibe a morfologia da camada de níquel sobre o substrato de silício para amostras recozidas a $200^{\circ} \mathrm{C}$. Foi possível observar ainda alguns pontos de ataque da solução de $\mathrm{KOH}$ ao substrato de Si (como destacado), porém em menor número do que os encontrados na Figura 3. Após a remoção da camada de níquel com uma solução de água régia diluída, constatou-se o ataque da solução de $\mathrm{KOH}$, porém em poucas regiões, como mostra a Figura 4 B).

A Figura 4 C) exibe a morfologia da camada de níquel sobre o substrato de silício para amostras recozidas a $250^{\circ} \mathrm{C}$. Foi possível observar que a cor da camada de níquel alterou-se e houve apenas um ponto de ataque da solução de $\mathrm{KOH}$ ao níquel. Após a remoção da camada de níquel, constatou-se que havia apenas um ponto de penetração da solução de $\mathrm{KOH}$ para dentro do substrato de silício, como mostra a Figura 4 D).

A Figura 5 exibe alguns pontos de penetração da solução de $\mathrm{KOH}$ para dentro do substrato de silício (direção (100)), após o término do processo de corrosão em amostras recozidas a $200^{\circ} \mathrm{C}$. 


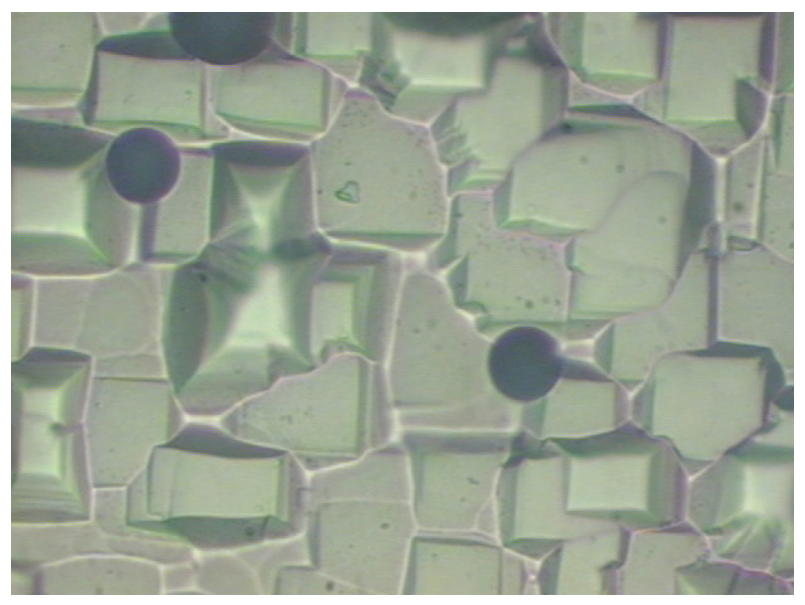

Figura 5: Pontos de penetração da solução de KOH para dentro do substrato de silício (direção 100), após o término do processo de corrosão.

De acordo com os resultados experimentais de Coe e Roderick [21], o tratamento térmico promove o crescimento de uma camada de $\mathrm{Ni}_{2} \mathrm{Si}$ entre o níquel e o silício. Essa camada é responsável pela aderência do filme ao substrato e exibe também resistência química na presença de soluções de KOH com concentrações diversas [20], sendo praticamente inerte quando exposta à tal meio [12]. Para a temperatura de $250^{\circ} \mathrm{C}$, forma-se também a fase $\mathrm{NiSi}$, porém em quantidades não significativas. Durante o processo, o filme de Ni não se desprende do substrato de Si. 
A topografia da camada de níquel antes do tratamento térmico e da camada $\mathrm{Ni}_{2} \mathrm{Si}$ formada sobre o substrato de silício foi analisada através da técnica de microscopia de força atômica (AFM). Os resultados obtidos estão mostrados na Figura 6:

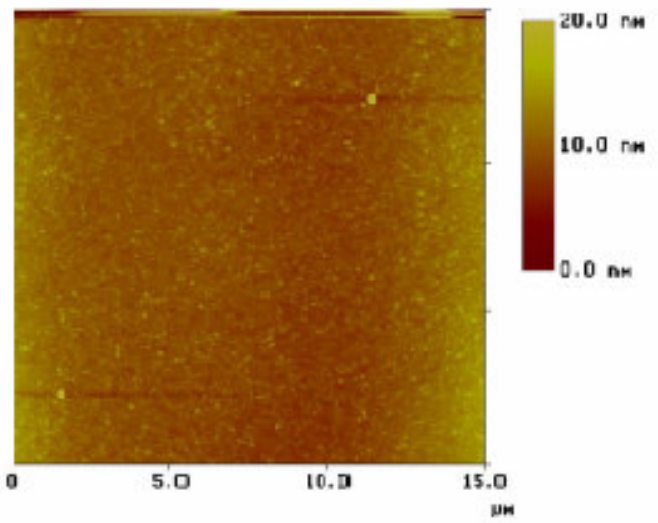

A)

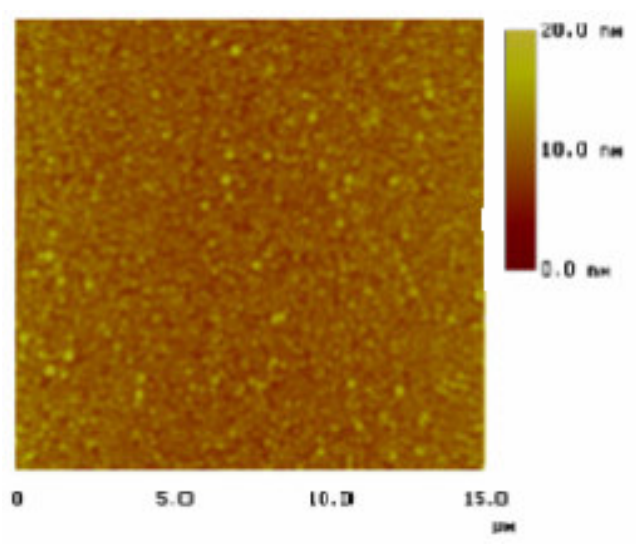

B)

Figura 6: Medidas de topografia. A) topografia da camada de níquel antes do tratamento térmico e B) topografia da camada de níquel após a formação do filme de $\mathrm{Ni}_{2} \mathrm{Si}$.

A Figura 6 A) mostra a rugosidade média quadrática da camada de níquel antes do tratamento térmico. O valor obtido esteve em torno de $2.9 \mathrm{~nm}$. A rugosidade média quadrática para a amostra com a camada de $\mathrm{Ni}_{2} \mathrm{Si}$ formada esteve em torno de $10.6 \mathrm{~nm}$, como mostra a Figura $6 \mathrm{~B}$ ). Através das imagens é possível perceber que a fase $\mathrm{Ni}_{2} \mathrm{Si}$ possui grãos maiores que o filme de níquel propriamente dito, devido ao seu crescimento bidirecional. A razão entre a reação de consumo do silício pelo níquel e a formação do siliceto de níquel é de 1: 1.88: 2.22 [20]. A existência de grãos maiores garantem a qualidade e resistência química do filme a soluções alcalinas contendo $\mathrm{KOH}$.

Uma análise posterior da composição dos filmes recozidos foi feita através da técnica RBS. Espectros, como o da Figura 7, foram ajustados através de um programa de simulação (RUMP), que indicou que o filme possuía a estequiometria $\mathrm{Ni}_{2} \mathrm{Si}$. Revelou-se também que alguns filmes depositados exibiam algum conteúdo de $\mathrm{O}$. A seta na Figura 7 indica a formação do $\mathrm{Ni}_{2} \mathrm{Si}$. $\mathrm{O}$ encurvamento do pico referente ao níquel indica o seu consumo e o crescimento do patamar referente ao silício indica que ocorreu a reação de formação da camada de $\mathrm{Ni}_{2} \mathrm{Si}$. 


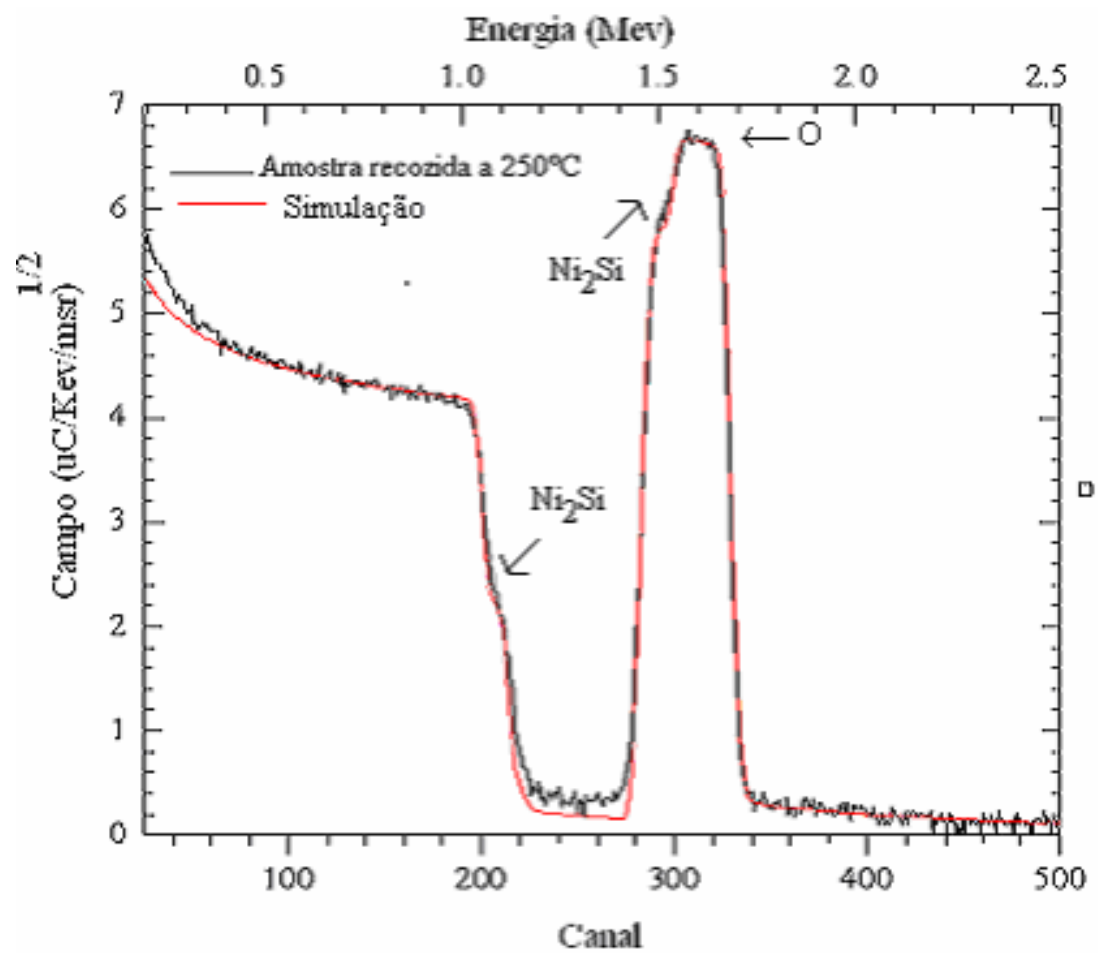

Figura 7: Análise RBS da formação da camada de $\mathrm{Ni}_{2} \mathrm{Si}$. O programa de simulação forneceu uma estequiometria de $2: 1$.

Para amostras sinterizadas a $250^{\circ} \mathrm{C}$, a espessura final de $\mathrm{Ni}_{2} \mathrm{Si}$ foi estimada, pela modelagem de Arrhenius [21], como sendo $10 \AA ̊$. Ao utilizarmos uma temperatura de sinterização de $200^{\circ} \mathrm{C}$, uma camada mínima de $\mathrm{Ni}_{2} \mathrm{Si}$ também é formada ( menos de $0.1 \AA$ ).

Verificada a viabilidade do $\mathrm{Ni}_{2} \mathrm{Si}$ como material de máscara para soluções de $\mathrm{KOH}$, foram fabricadas as canaletas de acomodação de fibras ópticas. 


\section{Capítulo 4: Processos de fabricação de canaletas e guias de onda}

Neste capítulo, descreveremos as etapas de processo utilizadas na confecção de canaletas de acomodação de fibras ópticas e guias de onda. Uma abordagem teórica desses processos está explicitada no Apêndice A.

\subsection{Processos de fabricação de canaletas: procedimentos experimentais}

Para fabricar as canaletas de acomodação de fibras ópticas, utilizamos substratos de silício com o mesmo padrão descrito na seção 3.1. As etapas de processo utilizadas foram:

- Limpeza SPM + HF + RCA (seção 3.1).

- Deposição de 200 nm de níquel por evaporação térmica (seção 3.1 e Apêndice A).

- Definição fotolitográfica das canaletas

Para a definição das canaletas, foram utilizados os fotolitos mostrados na Figura 8:

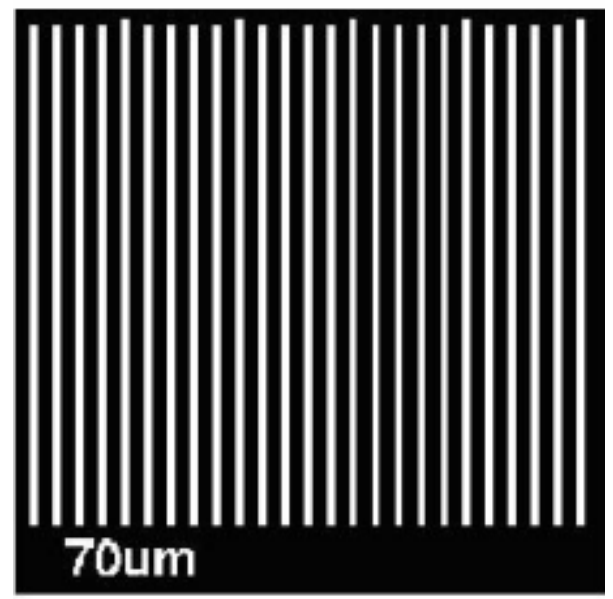

Figura 8: Máscara projetada para a realização do processo litográfico. Padrões de linhas utilizados para a obtenção de canaletas de acomodação de fibras ópticas.

O processo litográfico foi feito através de uma seqüência convencional (Apêndice A) utilizando o fotorresiste OFPR 5000.

- Sinterização em um forno convencional com ambiente de $\mathrm{N}_{2}$, a temperaturas de 200 e $250^{\circ} \mathrm{C}$, por um tempo de 20 minutos (formação de $\mathrm{Ni}_{2} \mathrm{Si}$ ).

- Corrosão úmida anisotrópica das amostras (Apêndice A) em uma solução contendo $\mathrm{KOH}\left(27 \%\right.$ a $\left.60^{\circ} \mathrm{C}\right)$ por tempos de 1,5 e 2 horas. 
- Remoção do $\mathrm{Ni}_{2} \mathrm{Si}$ utilizando uma solução de água régia diluída $\left(3 \mathrm{HCl}+1 \mathrm{HNO}_{3}+2\right.$ $\left.\mathrm{H}_{2} \mathrm{O}\right)$.

\subsection{Processos de fabricação de canaletas: resultados e discussões}

Os resultados obtidos para amostras com $\mathrm{Ni}_{2} \mathrm{Si}$ obtido a $200^{\circ} \mathrm{C}$ por 20 minutos, após 1,5 horas de corrosão com $\mathrm{KOH}(27 \%)$ na temperatura de $60^{\circ} \mathrm{C}$, estão mostrados na Figura 9, que continua na próxima página.

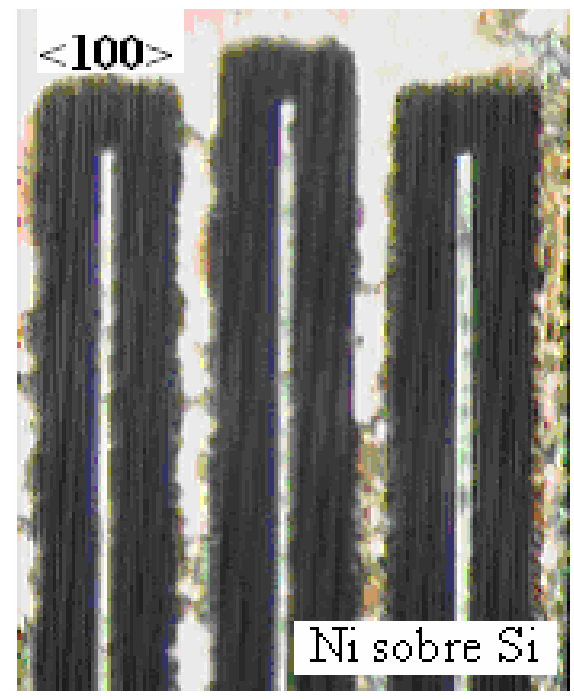

A)

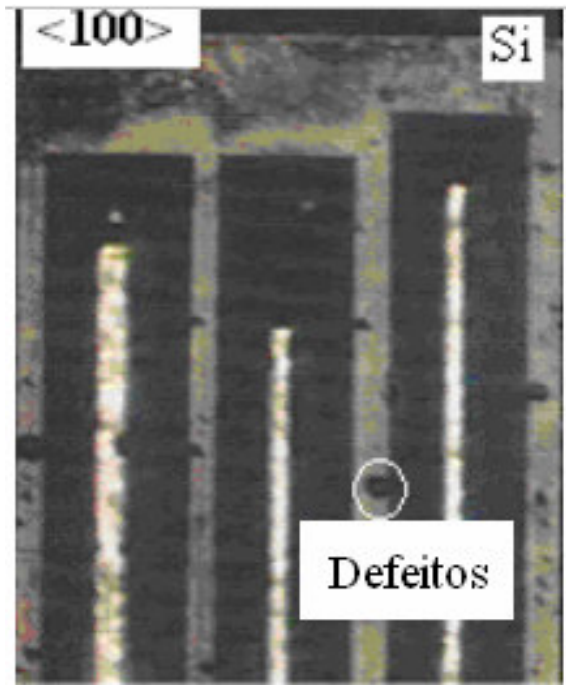

B) 


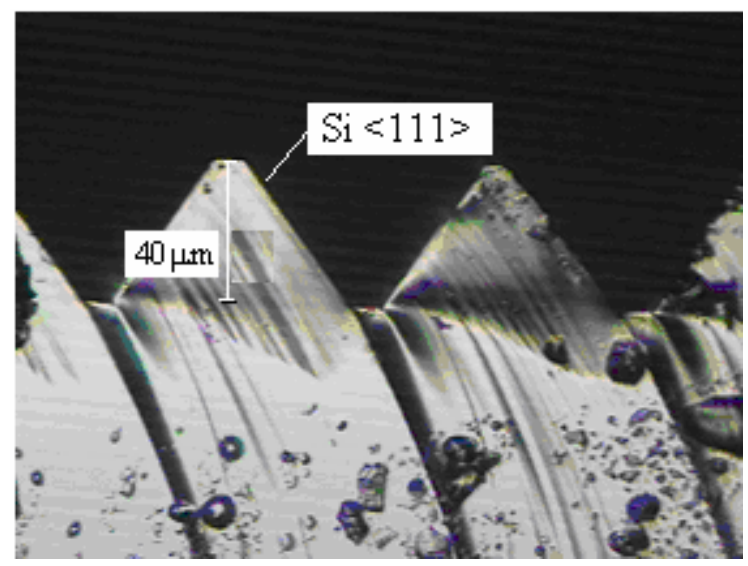

C)

Figura 9: Canaletas com largura de $70 \mu \mathrm{m}$ corroídas após 1,5 hora de corrosão a uma temperatura de $200^{\circ} \mathrm{C}$, por 20 minutos. A) vista superior das canaletas antes da remoção do níquel, B) vista superior das canaletas após remoção do níquel e C) vista das canaletas em seção transversal.

A Figura 9 A) mostra a vista superior das canaletas, antes da etapa da remoção do níquel. Foi possível observar que muitos pontos do material da máscara foram atacados pela solução de corrosão e houve regiões onde o filme de níquel se destacou do substrato de silício. Após o processo de remoção do filme, observou-se a penetração da solução de $\mathrm{KOH}$ para dentro do substrato de silício e a formação de pontos escuros sobre a sua superfície, como mostra a Figura 9 B). Nesta figura também é possível observar que o encontro dos planos (100) e (111) do substrato de silício ainda não havia sido ocorrido, através da visualização do fundo do canal. A Figura 9 C) mostra a imagem em seção transversal do perfil obtido, que assumiu um formato trapezoidal com profundidade de $40 \mu \mathrm{m}$.

Os resultados obtidos para amostras recozidas a $200^{\circ} \mathrm{C}$ por 20 minutos, após 2 horas de corrosão, estão mostrados na Figura 10: 


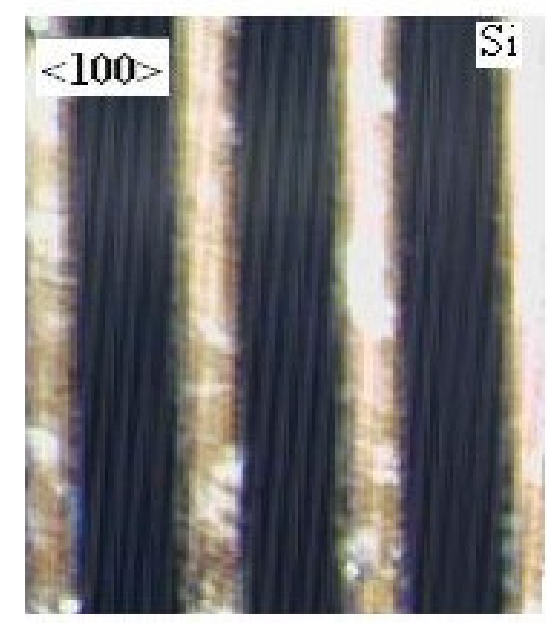

A)

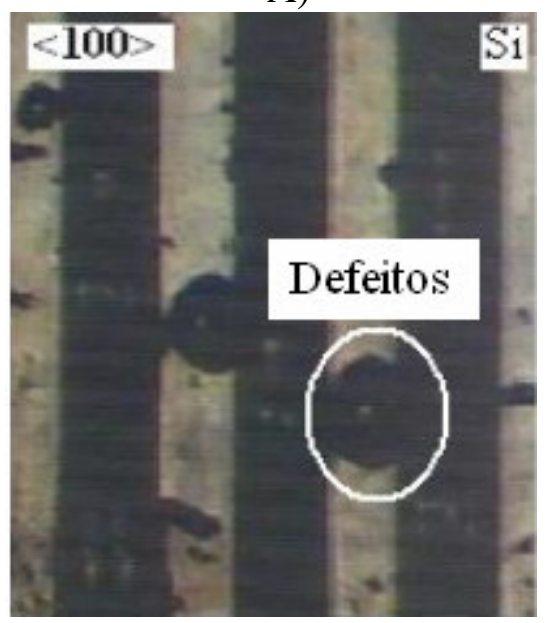

B)

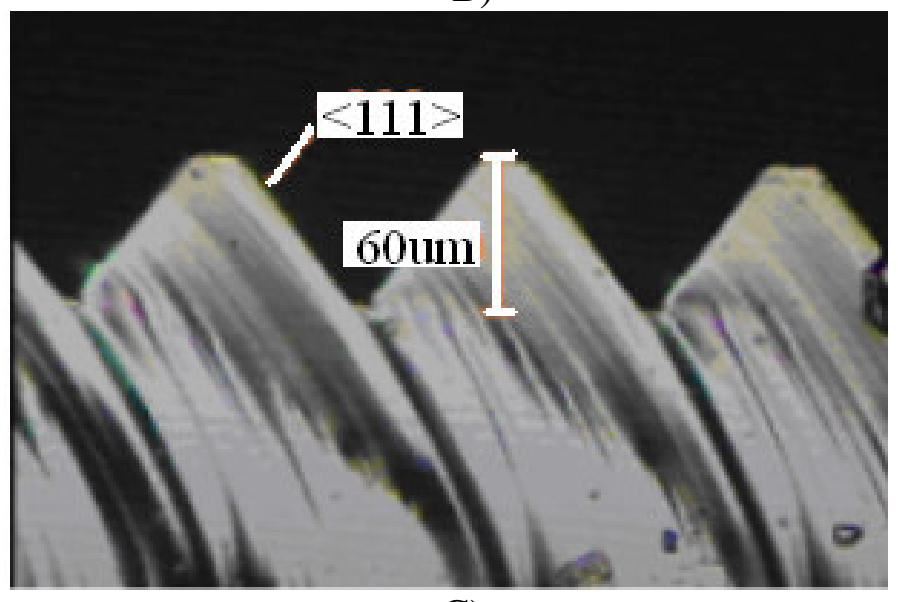

C)

Figura 10: Canaletas com largura de $70 \mu \mathrm{m}$ corroídas após 2 horas de corrosão a uma temperatura de $200^{\circ} \mathrm{C}$, por 20 minutos. A) vista superior das canaletas antes da remoção do níquel, B) vista superior das canaletas após a remoção do níquel e C) vista das canaletas em seção transversal. 
Através da Figura 10 A) e B) foi possível observar que o filme de níquel não resistiu quimicamente à solução de corrosão, que atacou em alto grau a superfície do substrato de silício. A Figura 10 C) mostra a imagem em seção transversal do perfil obtido, onde é possível visualizar o formato em V, resultante da grande diferença das taxas de corrosão dos planos (100) e (111) do silício em $\mathrm{KOH}$ [7] A profundidade medida neste ponto foi de $60 \mu \mathrm{m}$.

Nas amostras recozidas a $200^{\circ} \mathrm{C}$ não foi criada uma interface entre o filme de níquel e o substrato de silício. Por esta razão, o material de máscara não pôde resistir quimicamente à solução de corrosão.

Os resultados obtidos para amostras recozidas a $250^{\circ} \mathrm{C}$ por 20 minutos, após 1,5 hora de corrosão, estão mostrados na Figura 11:

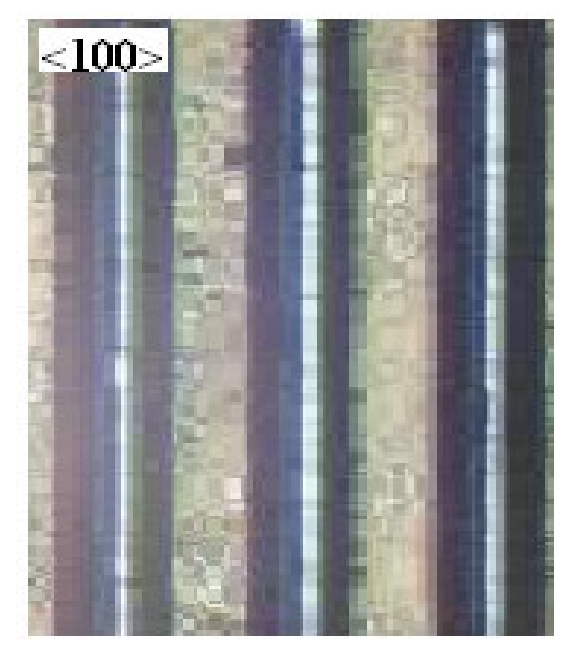

A)

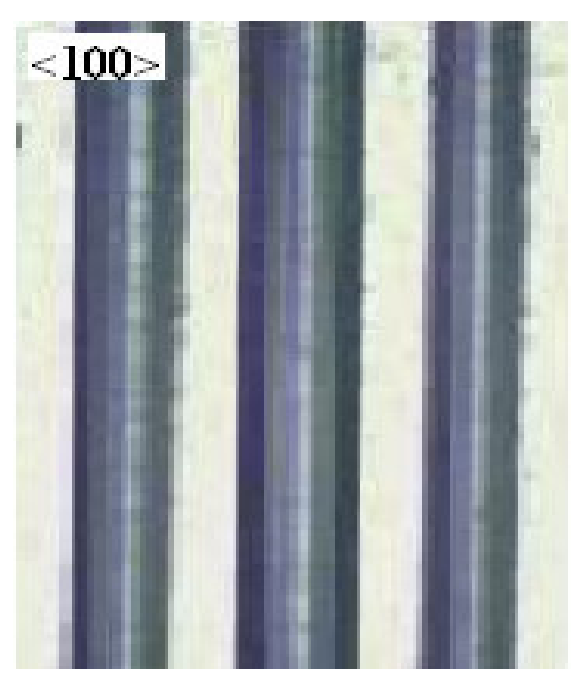

B) 


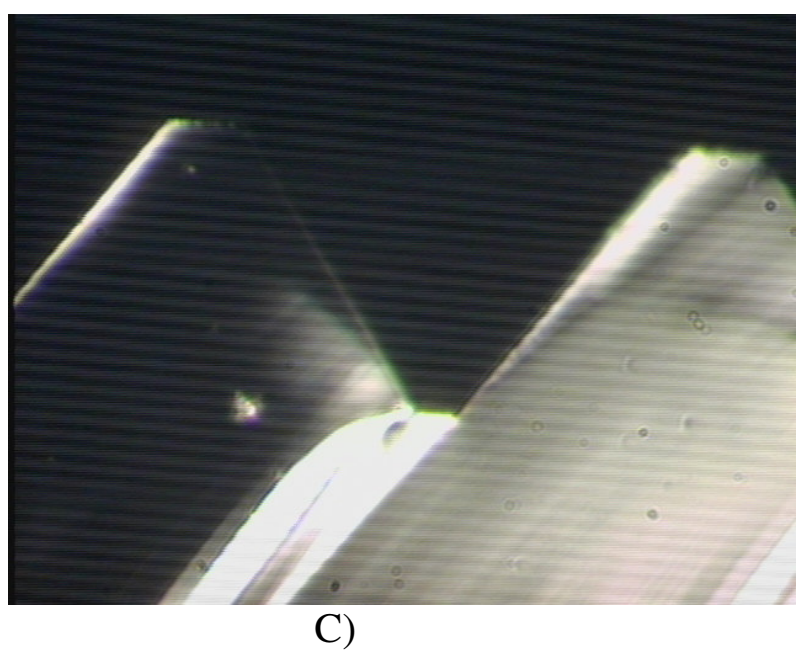

Figura 11: Canaletas com largura de $70 \mu \mathrm{m}$ corroídas após 1,5 hora de corrosão a uma temperatura de $250^{\circ} \mathrm{C}$, por 20 minutos. A) vista superior das canaletas antes da remoção do $\mathrm{Ni}_{2} \mathrm{Si}$, B) vista superior das canaletas após a remoção do $\mathrm{Ni}_{2} \mathrm{Si}$ e C) vista das canaletas em seção transversal.

A Figura 11 A) mostra a vista superior das canaletas antes da remoção do filme de $\mathrm{Ni}_{2} \mathrm{Si}$. Observou-se que, nessas amostras, a máscara de $\mathrm{Ni}_{2} \mathrm{Si}$ não foi atacada pela solução de corrosão. Após o processo de remoção do filme de $\mathrm{Ni}_{2} \mathrm{Si}$ com água régia diluída, não foram observados pontos de penetração da solução de corrosão para dentro do substrato de silício, como está mostrado na Figura 11 B).

A Figura 11 C) mostra a imagem em seção transversal das microestruturas corroídas. Neste processo, a canaleta em V ainda não pôde ser observada, mas sim uma estrutura trapezoidal com profundidade de $40 \mu \mathrm{m}$.

Os resultados obtidos para amostras recozidas a $250^{\circ} \mathrm{C}$ por 20 minutos, após 2 horas de corrosão, estão mostrados na Figura 12: 


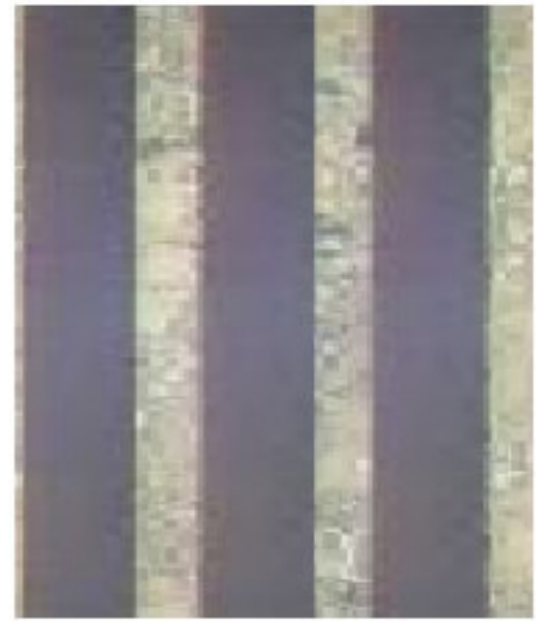

A)

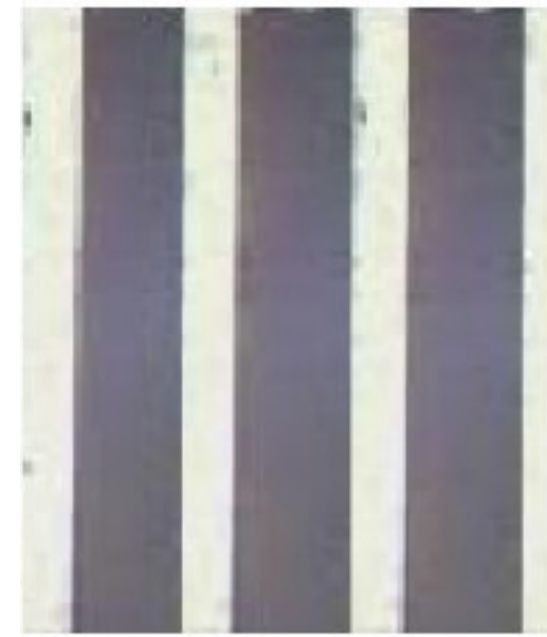

B)

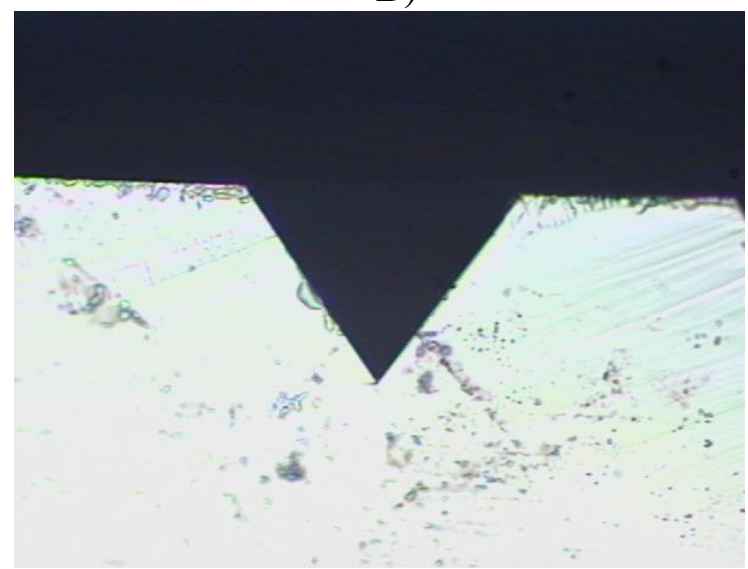

C)

Figura 12: Canaletas com largura de $70 \mu \mathrm{m}$ corroídas após 2 horas de corrosão a uma temperatura de $250^{\circ} \mathrm{C}$, por 20 minutos. A) vista superior das canaletas antes da remoção do $\mathrm{Ni}_{2} \mathrm{Si}, \mathrm{B}$ ) vista superior das canaletas após a remoção do $\mathrm{Ni}_{2} \mathrm{Si}$ e $\mathrm{C}$ ) vista das canaletas em seção transversal. 
Antes da etapa de remoção do $\mathrm{Ni}_{2} \mathrm{Si}$ Figura $12 \mathrm{~A}$ ), pudemos observar que ele teve resistência química suficiente para garantir que a solução de corrosão não atacasse a superfície do substrato, independentemente do decorrer do tempo de processo. Após a remoção da camada de $\mathrm{Ni}_{2} \mathrm{Si}$, não foram observados pontos de penetração da solução de $\mathrm{KOH}$ para dentro do substrato de silício, como mostra a Figura 12 B). A Figura 12 C) mostra a imagem em seção transversal das canaletas obtidas, onde é possível observar uma forma bem definida e com paredes livres de rugosidade. A profundidade medida neste ponto foi de $60 \mu \mathrm{m}$.

Os processos de corrosão foram efetuados a uma temperatura média de $61,5^{\circ} \mathrm{C}$. Para essa temperatura, a taxa de corrosão do $\mathrm{Si}$ por $\mathrm{KOH}$ a $27 \%$, na direção (100) foi obtida como $R_{(100)}=33,1 \mu \mathrm{m} / \mathrm{h}$. Seidel et al [7] reportam que esta taxa está em torno de $30 \mu \mathrm{m} / \mathrm{h}$.

Em algumas canaletas obtidas, foi possível observar o surgimento de imperfeições no plano (111), como mostra a Figura 13. Uma possível causa do fato descrito é um eventual desalinhamento da máscara litográfica com os planos (111) do silício.

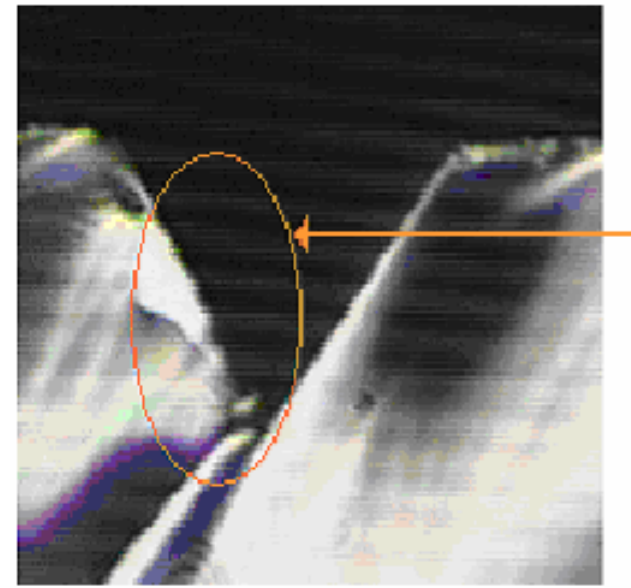

A)

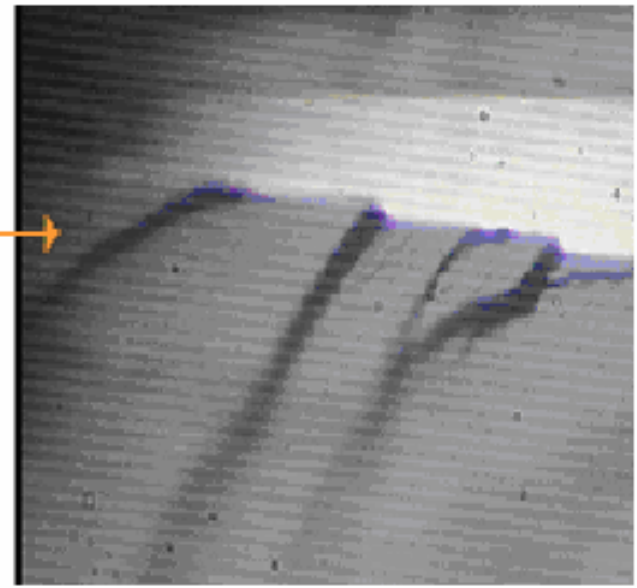

B)

Figura 13: Imperfeições no plano (111) do silício . A)região demarcada como referência e B) ampliação de (A) para melhor visualização de tais imperfeições.

A Figura 14 mostra a análise SEM para as canaletas obtidas após 2 horas de corrosão, utilizando-se temperaturas de sinterização de $250^{\circ} \mathrm{C}$ : 


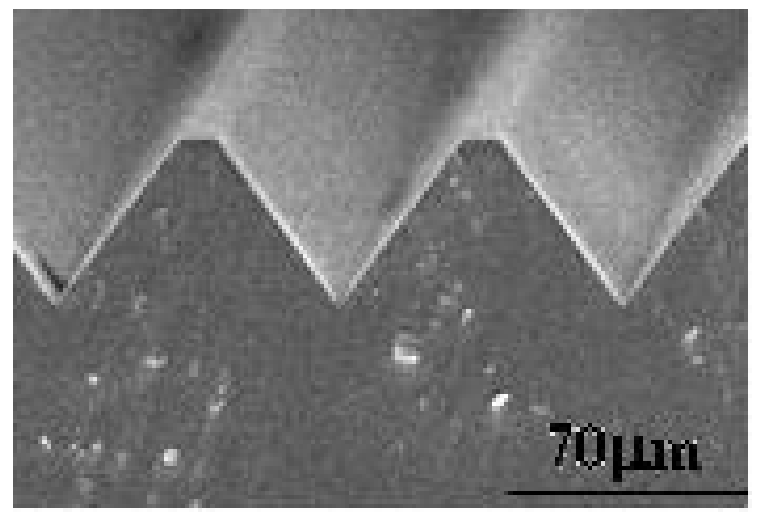

Figura 14: Análise SEM para as canaletas obtidos após 2 horas de corrosão, utilizando-se temperaturas de sinterização de $250^{\circ} \mathrm{C}$.

Nesta figura, temos canaletas com largura de $70 \mu \mathrm{m}$ e profundidade de $60 \mu \mathrm{m}$, corroídas na solução de $\mathrm{KOH}(27 \%$ - 60C). Pudemos verificar que as paredes dos poços apresentam baixa rugosidade e que houve o encontro dos planos (100) e (111) do silício. Através da geometria obtida também podemos afirmar que a máscara resistiu muito bem ao ataque químico da solução de corrosão.

Na Figura 15, é possível visualizar um grupo de estruturas corroídas, com as mesmas características das estruturas relatadas na Figura 14.

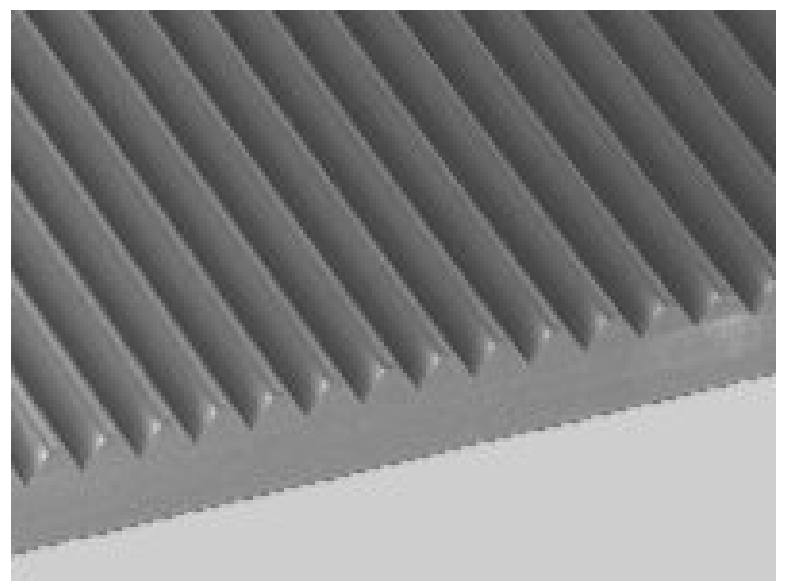

Figura 15: Imagem SEM mostrando um grupo de canaletas corroídas.

\subsection{Processos de fabricação dos guias de onda: procedimentos experimentais}

As etapas de processo utilizadas para a fabricação do guia de onda de teste para alinhamento com as canaletas e acoplamento óptico foram: 
- Limpeza de lâminas (seção 3.1).

- Oxidação térmica úmida (Apêndice A).

Nesta etapa, a lâmina de silício foi exposta à um ambiente oxidante $\left(\mathrm{O}_{2}, \mathrm{H}_{2} \mathrm{O}\right)$ em altas temperaturas, onde pudemos controlar a espessura do filme alterando os parâmetros do processo, por exemplo, temperatura, concentração do elemento oxidante ou o tempo de processo.

A baixa rugosidade, alta qualidade estrutural e a excelente uniformidade são características ideais para a fabricação de guias ópticos de qualidade [26].

$\mathrm{O}$ processo de crescimento térmico de $\mathrm{SiO}_{2}$ foi realizado em um forno convencional nas condições mostradas na Tabela 1:

Tabela 1: Parâmetros de processo para a obtenção do filme de $\mathrm{SiO}_{2}$ térmico.

\begin{tabular}{|c|l|}
\hline${\text { FLUXO DE } \mathrm{O}_{2}}$ & $21 / \mathrm{min}$ \\
\hline TEMPERATURA & $1150^{\circ} \mathrm{C}$ \\
\hline TEMPO & 10 horas \\
\hline ESPESSURA ESPERADA & $2 \mu \mathrm{m}$ \\
\hline
\end{tabular}

Uma análise por elipsometria forneceu a espessura e o índice de refração da camada de $\mathrm{SiO}_{2}$ como sendo $2 \pm 0.1 \mu \mathrm{m}$ e $1,463 \pm 0,002$, respectivamente.

A rugosidade superficial do filme obtido foi analisada em um equipamento de AFM da Digital Instruments em áreas de $15 \times 15 \mu \mathrm{m}$. O valor médio de rugosidade RMS medido para o filme obtido foi de $0,24 \pm 0,03 \mathrm{~nm}$.

Observamos que o filme apresentou uma baixa rugosidade superficial que é um fator essencial para obtermos guias ópticos com baixa atenuação por espalhamento na interfaces [28].

- Deposição de $\mathrm{Si}_{3} \mathrm{~N}_{4}$ por LPCVD (Apêndice A).

Os filmes de $\mathrm{Si}_{3} \mathrm{~N}_{4}$ foram obtidos por LPCVD em um sistema caseiro construído na UNICAMP. Para a deposição do filme, foram utilizados os parâmetros contidos na Tabela 2. 
Tabela 2: Parâmetros de processo utilizados para a obtenção de $\mathrm{Si}_{3} \mathrm{~N}_{4}$.

\begin{tabular}{|c|l|}
\hline PRESSÃO & 1.51 Torr \\
\hline FLUXO DE SILANA/ARGÔNIO & $600 \mathrm{sccm}$ \\
\hline TEMPO/TEMPERATURA & $120 \mathrm{~min}-720^{\circ} \mathrm{C}$ \\
\hline
\end{tabular}

A análise elipsométrica forneceu a espessura e o índice de refração da camada de $\mathrm{Si}_{3} \mathrm{~N}_{4}$ como sendo $3 \pm 0.1 \mu \mathrm{m}$ e $2,071 \pm 0,006$, respectivamente.

A rugosidade superficial do filme obtido foi analisada em um equipamento de AFM em áreas de $15 \times 15 \mu \mathrm{m}$. O valor médio de rugosidade RMS medido para o filme obtido foi de $0,26 \pm$ $0,05 \mathrm{~nm}$.

- Fotogravação do guia óptico de teste por litografia.

A definição dos guias ópticos de teste, sob os filmes de $\mathrm{Si}_{3} \mathrm{~N}_{4}$, foi realizada por um processo litográfico óptico convencional (Apêndice A) utilizando o fotorresiste OFPR 5000. A máscara litográfica é composta de uma placa de quartzo $(10$ x $10 \mathrm{~cm}) \mathrm{com}$ um filme de acetato, onde a geometria dos guias foi previamente transferida por uma exposição por UV.

Os parâmetros de deposição, exposição e revelação foram ajustados de tal modo que obtivemos uma boa resolução em todas as estruturas contidas no padrão dos guias ópticos.

- Corrosão das camadas de $\mathrm{Si}_{3} \mathrm{~N}_{4}$ e $\mathrm{SiO}_{2}$ até o substrato e remoção do fotorresiste

Os guias planares foram obtidos por uma corrosão úmida dos filmes de $\mathrm{Si}_{3} \mathrm{~N}_{4}$ e de $\mathrm{SiO}_{2}$ até o substrato utilizando BOE [12].

- Remoção do fotorresiste

Após o processo de corrosão para a confecção dos guias, a camada de fotorresiste foi removida utilizando-se o seguinte procedimento:

- imersão em acetona aquecida por 10 minutos;

- imersão em álcool isopropílico;

- lavagem em água DI;

- imersão em uma solução de $330 \mathrm{ml}$ de $\mathrm{H}_{2} \mathrm{SO}_{4}+170 \mathrm{ml}$ de $\mathrm{H}_{2} \mathrm{O}_{2}$;

- lavagem em água DI por 5 minutos. 


\subsection{Processo de fabricação dos guias de onda: resultados e discussão}

A Figura 16 mostra a imagem SEM de um guia planar obtido com largura de $4 \mu \mathrm{m}$ e profundidade de $5 \mu \mathrm{m}$.

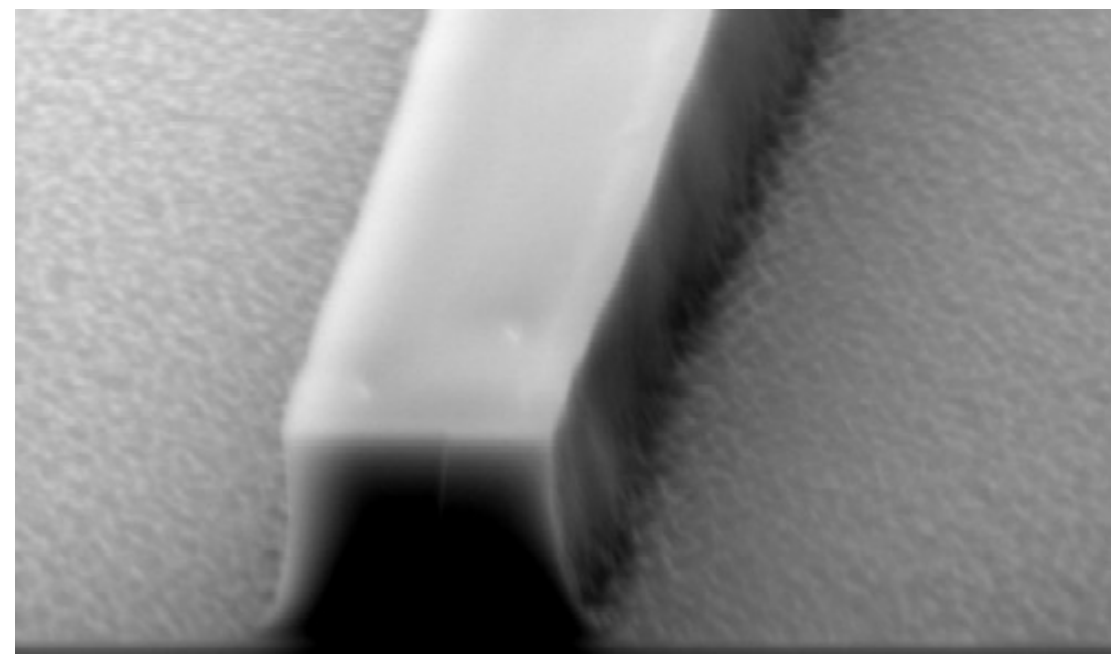

Figura 16: imagem SEM de um guia planar obtido com largura de $4 \mu \mathrm{m}$ e altura de $5 \mu \mathrm{m}$.

Este trabalho dá um enfoque principal no processamento de substratos de silício para obtenção de canaletas de acomodação de fibras ópticas utilizando $\mathrm{Ni}_{2} \mathrm{Si}$ como material de máscara. A construção do guia da Figura 16 foi feita somente para aplicação prática do processo até aqui desenvolvido (alinhamento entre as canaletas e um guia de onda para posterior inserção de uma fibra óptica). Por essa razão, este é um guia de onda de teste simples, contendo apenas uma camada de isolação e uma camada de guiamento. Maiores detalhes sobre este assunto encontram-se no Apêndice B.

\subsection{Fabricação de uma estrutura ilustrativa contendo canaletas e guias de onda alinhados: procedimentos experimentais}

Para a fabricação da estrutura ilustrativa, utilizamos as etapas de processos já definidas anteriormente e desenhadas a seguir: 


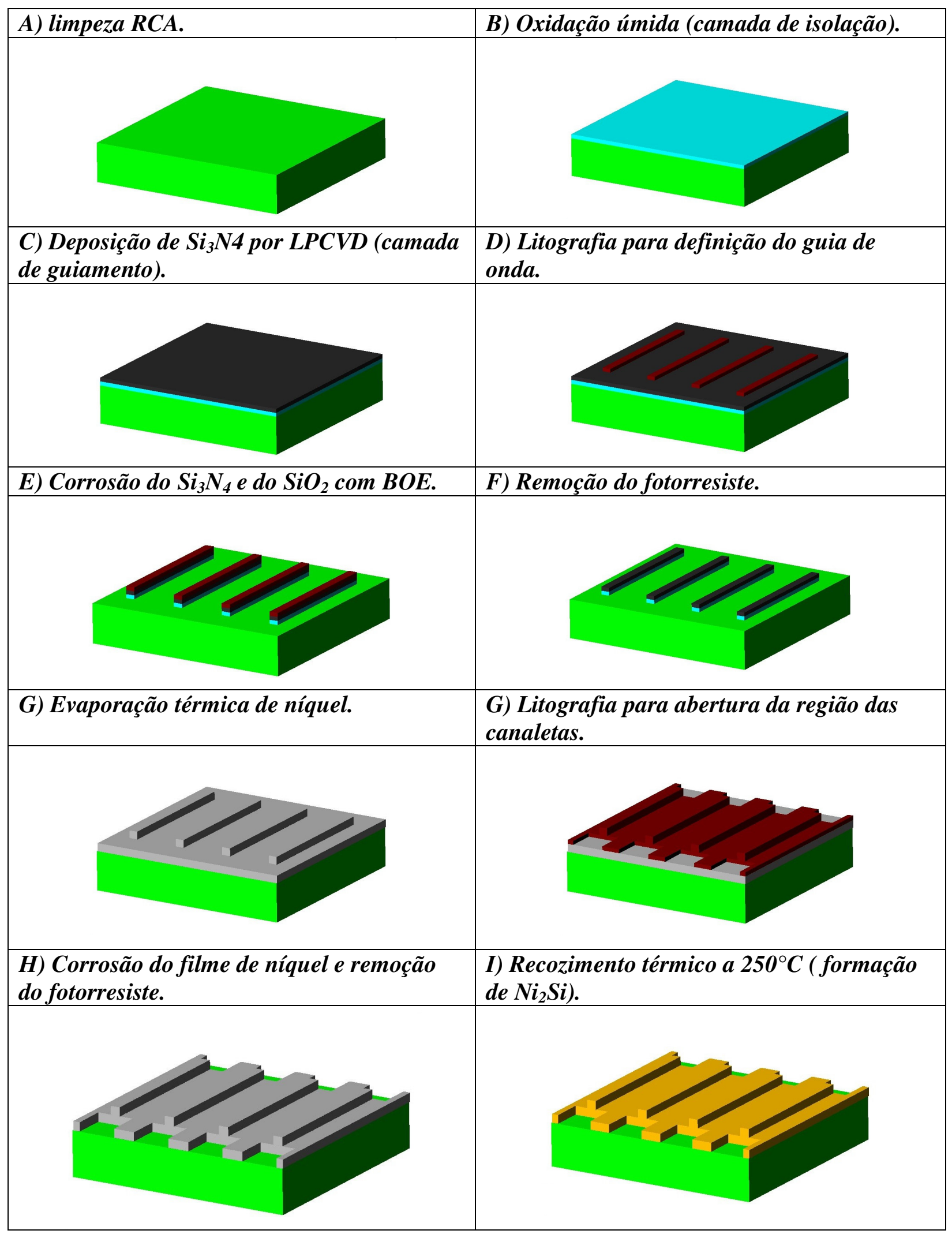




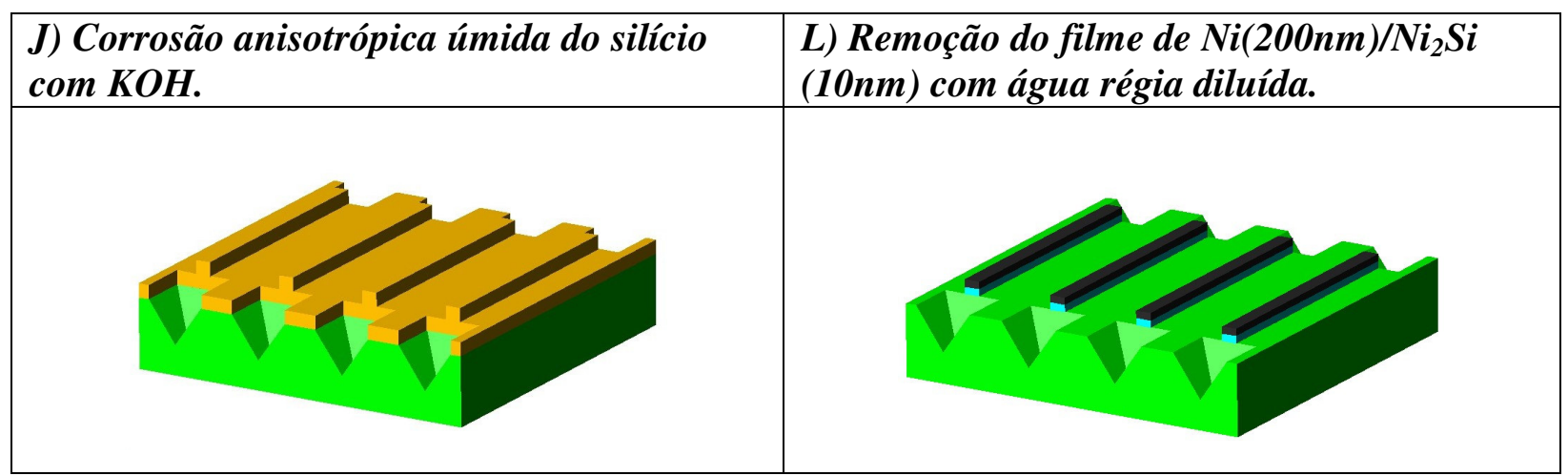

Figura 17: Etapas de processo para a fabricação de uma estrutura de teste contendo guias de onda e canaletas alinhados entre si.

\subsection{Fabricação de uma estrutura ilustrativa contendo canaletas e guias de onda alinhados: resultados e discussões}

A Figura 18 mostra a estrutura final obtida. As canaletas de acomodação para fibras ópticas possuem uma largura de $200 \mu \mathrm{m}$ e uma profundidade de $120 \mu \mathrm{m}$. Os guias de onda possuem uma largura de $4 \mu \mathrm{m}$ e uma espessura total de $5 \mathrm{um}$, sendo que a camada de isolação $\left(\mathrm{SiO}_{2}\right)$ possui 2 $\mu \mathrm{m}$, a camada de guiamento $\left(\mathrm{Si}_{3} \mathrm{~N}_{4}\right)$ possui $3 \mu \mathrm{m}$ e a camada de cobertura é o ar.

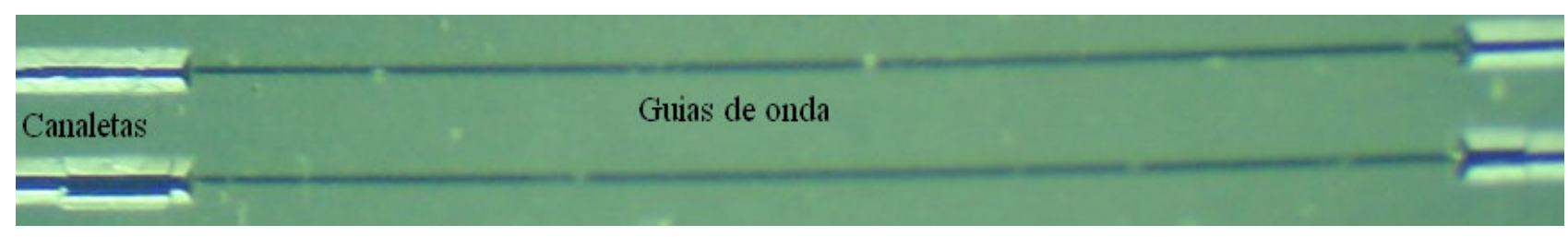

Figura 18: Conjunto contendo tanto as canaletas de acomodação de fibras ópticas quanto os guias de onda, alinhados entre si.

A Figura 19 mostra uma ampliação contendo um conjunto de guias de onda e canaletas obtidas. 


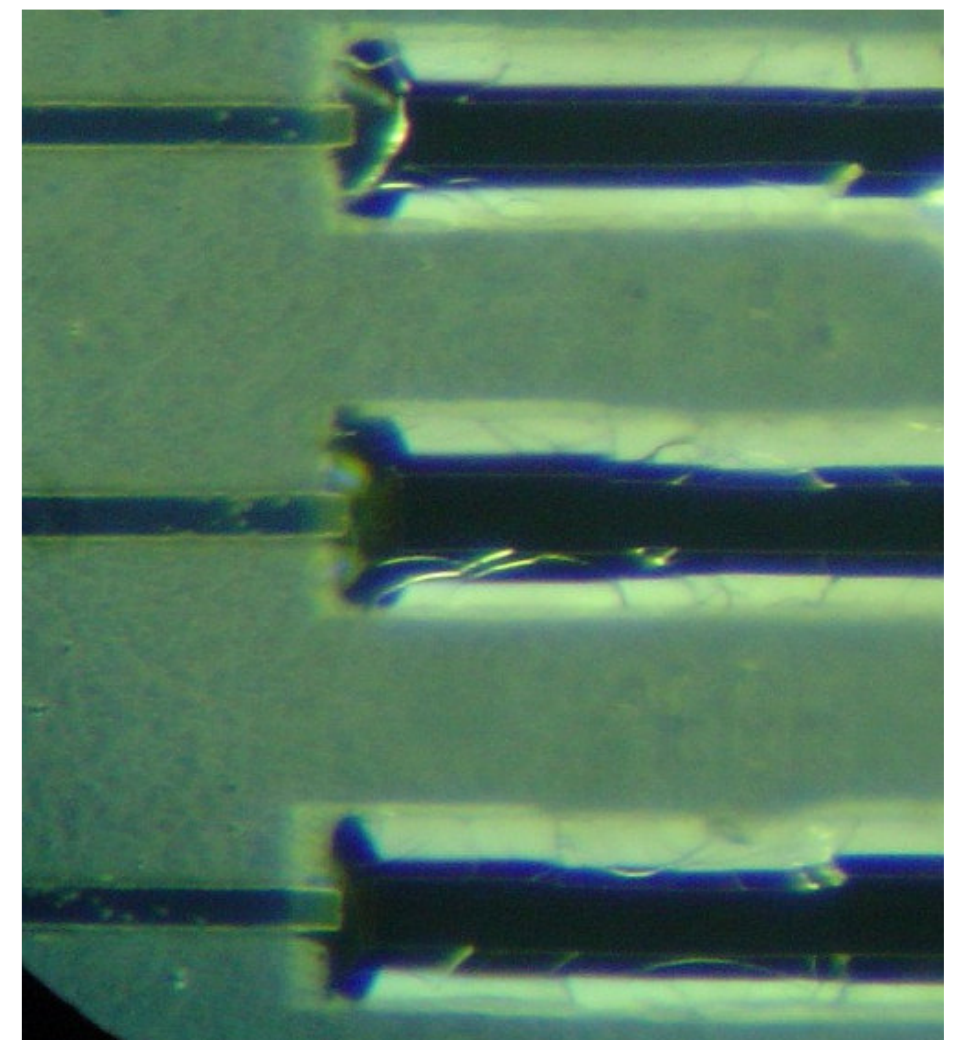

Figura 19: Ampliação contendo um conjunto de guias de onda e canaletas obtidas.

Observando as estruturas feitas de acordo com os procedimentos detalhados na seção 4.5, podemos ver que não houveram pontos de penetração da solução de $\mathrm{KOH}$ nem no substrato de silício nem na área ocupada pelos guias de onda, o que nos leva a crer que o filme interfacial de $\mathrm{Ni}_{2} \mathrm{Si}$ funciona perfeitamente como material de máscara e pode substituir os materiais tradicionalmente utilizados, que são o $\mathrm{SiO}_{2}$ e o $\mathrm{Si}_{3} \mathrm{~N}_{4}$.

Os guias de onda alinhados às canaletas servirão para um posterior teste e caracterização de um acoplamento óptico, que se dará pela inserção de uma fibra óptica dentro das canaletas, com o diâmetro da mesma ordem de grandeza da largura das canaletas. 


\section{Capítulo 5: Conclusões}

Neste trabalho, foram obtidos bons resultados utilizando uma estrutura $\mathrm{Ni} / \mathrm{Ni}_{2} \mathrm{Si}$, onde o $\mathrm{Ni}$ foi obtido por evaporação térmica e houve posterior recozimento térmico a baixa temperatura para aplicação como máscara em corrosões profundas. Inspeções e caracterizações feitas mostraram que o níquel, na sua fase de siliceto, em particular o $\mathrm{Ni}_{2} \mathrm{Si}$, possui uma boa adesão e rigidez mecânica a substratos de silício, sendo praticamente inerte a meio alcalinos, especialmente soluções concentradas de $\mathrm{KOH}$. Os resultados apresentados mostram a adequação do processo, que permitiu a fabricação de canaletas de acomodação de fibras ópticas de aproximadamente $60 \mu \mathrm{m}$ de profundidade.

A cinética de crescimento do $\mathrm{Ni}_{2} \mathrm{Si}$ está exponencialmente relacionada com a temperatura de processo Lei de Arrhenius). Para canaletas obtidas com $\mathrm{Ni}_{2} \mathrm{Si}$ fabricado a $200^{\circ} \mathrm{C}$, a superfície do substrato de silício foi danificada devido à penetração da solução de $\mathrm{KOH}$ através do filme de siliceto. Este fato ocorreu pois a esta temperatura, a camada de siliceto ainda não havia sido formada por toda a superfície do substrato. Aumentando-se a temperatura de recozimento para $250^{\circ} \mathrm{C}$, obtivemos canaletas com superfícies uniformes e livres de penetração de $\mathrm{KOH}$. A esta temperatura, temos uma camada de aproximadamente $10 \mathrm{~nm}$ de $\mathrm{Ni}_{2} \mathrm{Si}$ formada. Outros processos que requerem cavidades mais profundas, como a fabricação de membranas da ordem de $240 \mu \mathrm{m}$ para o acoplamento de fibras ópticas a dispositivos ópticos integrados, são igualmente acessíveis pela técnica proposta.

Em suma, uma camada de níquel evaporada termicamente seguida de um pós- tratamento térmico pode ser utilizada como máscara para corrosões químicas anisotrópicas em silício exposto a meios alcalinos. Essa técnica é simples e não dispendiosa se comparada a outros processos, nomeadamente à deposição de $\mathrm{Si}_{3} \mathrm{~N}_{4}$ ou ao crescimento de $\mathrm{SiO}_{2}$. Além disso, sendo um processo a baixas temperaturas, pode ser utilizada em substratos não tolerantes a processos que utilizem temperaturas elevadas.

Posteriormente, o processo desenvolvido foi aplicado para alinhar as canaletas a um guia de onda de teste, para uma futura inserção de uma fibra óptica para um acoplamento por endfire. 


\section{Capítulo 6: Sugestões para trabalhos futuros}

Para a continuidade deste trabalho, sugerimos os seguintes tópicos:

- construção de um rebaixamento por uma serra de corte para um melhor aproximação da fibra com o guia, eliminando a face do "V-groove" mais próxima do guia, conforme a Figura 20:

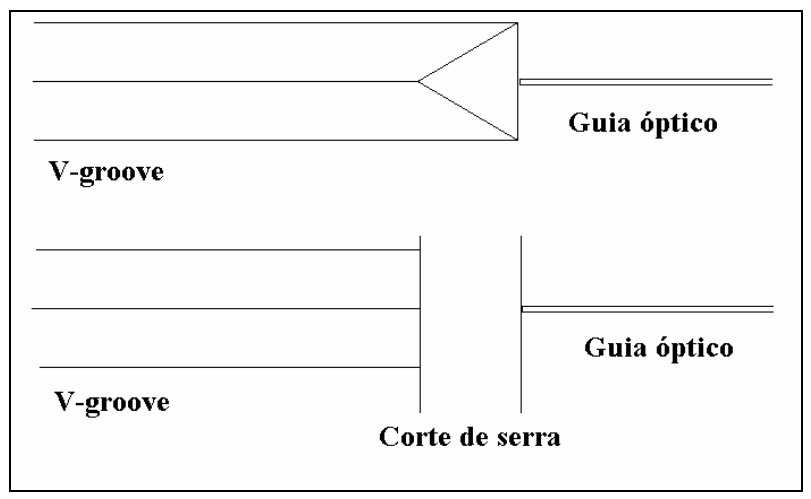

Figura 20: Indicação do corte de serra (vista de cima) para aproximação da fibra

- realizar testes de acoplamento com guias ópticos de diversas larguras com fibras ópticas utilizando os "V-groove"

- implementar uma interface eletrônica para a análise e medida dos sinais obtidos e correlacioná-los com a grandeza a ser medida. 


\section{Referências bibliográficas.}

[1]. LAWRENCE, A., Modern Inertial Technology: Navigation, Guidance and Control, Springer-Verlarg, New York, (1993).

[2]. NISHIHARA, H.; HARUNA, M.; SUHARA, T., Optical integrated circuits, McGrawHill Book Company, USA, (1989).

[3]. HEIDEMAN, R.G.; LAMBECK, P. V., Remote Opto Chemical Sensing with Extreme Sensitivity: Design, Fabrication and Performance of Pigtailed Integrated Optical Phase Modulated Mach - Zehnder Interferometer System, Sensor. Actuat. B-Chem. 61, 100, (1999).

[4]. CAMERON, K. H., Simple and Practical Technique for Attaching Single Mode Fibres to Waveguides, Electron. Lett. 20, 974, (1984).

[5]. LADOUCER, F.; LOVE, J. D.; "Silica-based Buried Channel Waveguides and Devices", Chapman \& Hall, 1996.

[6]. KOVACS, T. A.; MALUF, N. I.; PETTERSEN, K. E., Bulk Micromachining of Silicon, P. IEEE 86, 1536, (1998).

[7]. SEIDEL, H., Anisotropic Etching of Crystalline Silicon in Alkaline Solutions, J. Electromech. Soc. 137, 3612, (1990).

[8]. HEIDEMAN, R. G., Fabrication and Packaging of Integrated Chemo Optical Sensors, Sensor. Actuat. B-Chem. 35, 234, (1999).

[9]. KARMALKAR, S., R., MARJORIE, V., G., SUMITHRA, Adhesion of Electroless Nickel Plating on Polished Silicon, J. Adhes. Technol. 16, 1501, (2002).

[10]. MASSIMI, A.; FABRIZIO, D. E.; GENTILI, M.; PICCININ, D.; MARTINELLI, M., Fabrication of Optical Wave-Guides in Silica-on-Silicon by Nickel Electroplating, Jpn. J. Appl. Phys. 38, 6150 (1999).

[11]. MURARKA, S. P., Silicides for VLSI applications, Academic Press, New York, (1983).

[12]. WILLIAMS, K. R.; GUPTA, K.; WASILIK, M., Etch Rates for Micromachining Processing-Part II, J. Microelectromech. S. 12, 761 (2003).

[13].LIU, T.; SAMUELS, Prism Waveguide Coupler Model, J. Opt. Soc. Am. A 21,1322, (2004). 
[14]. MURPHY, T. E.; HASTINGS, J. T., Fabrication and Characterization of Narrow - Band Bragg - Reflection Filters in Silicon - on - Insulator Ridge Waveguides, J. Lightwave Technol. 19, 1938, (2001).

[15].LLOBERA, H. A.; PLAZA, J. A.; SALINAS, A.; BERGANZO, J.; GARCIA, J.; ESTEVE, J.; DOMINGUEZ, C., Technology Aspects on the Fabrication of SiliconBased Optical Accelerometer With Arrow Structures, Sensor. Actuat. A 110, 395 (2004).

[16]. MAYER, K. M., United States Patent, Method For Producing Optical Polymer Components Having Integrated Fiber Chip Coupling By Means Of Casting Technology, Patent Number: 5, 526, 454, (1996).

[17]. SHIN, H. J.; CHOI, J., H.; YANG, H. J., Patterning of Ferroeletric Nanodot Arrays Using a Silicon Nitride Shadow Mask, Appl. Phys. Lett 87, 110, (2005).

[18]. COLGAN, E. G., Activation Energy for $\mathrm{Ni}_{2} \mathrm{Si}$ e NiSi formation messured over a wide range of ramp rates, Thin Solid Films 279, 193, (1996).

[19]. MUKAI, R., OSAWA, H., TSUSHIKAWA, H., VMIC Conf. Proc, 343, (1994).

[20]. QIN, M.; POON, M. C.; YUEN, C. Y., A study of Nickel Silicide Film as a Mechanical Material, Sensors and Actuators A Phys. 87, 90, (2000).

[21]. COE, D.; RHODERICK, E. H., Silicide Formation in Ni-Si Schottky Barrier Diodes, J. Phys. D: Appl. Phys. 9, 965, (1976).

[22].DALDOSSO, N.; MELCHIORRI, M.; RIBOLI, F.; GIRARDINI, M.; UCKER, G.; CRIVELLARI, M.; BELLUTI, P.; LUI, A.; PAVESI, L, Fabrication and Optical Characterization of Thin two-Dimensional $\mathrm{Si}_{3} \mathrm{~N}_{4}$ Waveguides, Mat. Sci. Semicon. Proc. 7, 453, (2004).

[23]. YI, S. H.; VON PREISSIG, F. J.; KIM, E. S., Electroless Nickel Films: Properties and Fabricated Cavity Structure, J. Microelectromech. S. 11, 293, (2002).

[24]. NIWA, D.; HOMMA, T.; OSAKA, T., Deposition Mechanism of Ni on Si (100) Surfaces in Aqueous Alkaline Solution, J. Phys. Chem. B 28, 9900, (2004).

[25]. FUKUI, Técnicas de Microscopia de Tunelamento de Elétrons (MTE) e Microscopia de Força Atômica (MFA) Aplicadas ao Estudo de Superfícies de Grafite e Diamante, Tese de Mestrado/FEEC-UNICAMP, Abril 1992. 
[26]. DOBELI, M., Subtraction tool for the analysis of RBS data, Nuclear Instruments and Methods in Physics Research Section, 249, 133, (2006).

[27]. POLLOCK, C., Fundamentals of Optoelectronics, Chicago, Irwin, 1995.

[28]. KINGSLAKE, R., Applied Optics and Optical Engineering, IV, Parte 1, 31, (1967).

[29]. WOLF, S.; TAUBER, R. N., Silicon Processing For The VLSI Era, Springer, New York, 1990.

[30]. BRECHT, A.; GAUGLITZ, G., Recent Developments in Optical Transducers for Chemical or Biochemical Applications, Sensor. Actuat. B-Chem. 38, 1, (1997).

[31]. MADOU, M. J., Fundamentals of Microfabrication, CRC Press, New York, (1997).

[32]. HUANG, H. W.; KAO, C. C.; HSUEH, T. H.; YU, C. C.; LIN, C. F.; CHU, J. T.; KUO, H. C.; WANG, C., Fabrication of GaN-based Nanorod Light Emitting Diodes Using Self-Assemble Nickel Nano-Mask and Inductively Coupled Plasma Reactive Ion Etching, Mat. Sci. Eng. B-Solid 113, 125, (2004).

[33]. LAMBECK, P. V., Integrated Opto - Chemical Sensor, Sensor. Actuat. B-Chem. 8, 103, (1992).

[34].PORTE, H.; GOREL, V.; KIRYENCO, S.; GOEDGEBUER, S.; DANIAL, W; BLIND, P., Imbalanced Mach-Zhender Interferometer Integrated in Micromachining Silicon Substrate for Pressure Sensor, J. Lightwave Technol. 17, 229, (1999).

[35]. EISENSTEIN, G.; KOROTKY, S.; STULZ, L.; VESELKA, J.; JOPSON, R.; HALL, K., Antireflection Coatings on Lithium Niobate Waveguide Devices Using Eletron Beam Evaporated Yttrium Oxide, Eletron. Lett. 29, 974, (1993).

[36]. BLOEM, J.; GILING, L. J., Current Topics in Material Science, Kladis, 1987.

[37].ZAPPE, H. P., Introduction to Semiconductor Integrated Optics, Artech House, Boston, (1995).

[38]. PHILLIP, H. R., Infrared Optical - Properties of $\mathrm{SiO}_{2}$ and $\mathrm{SiO}_{2}$ Layers on Silicon, Jpn. J. Appl. Phys. 50, 1053, (1979).

[39]. STERN, M. B., Pattern Transfer for Diffractive and Refractive Microoptics, Microelectron. Eng. 34, 299, (1997).

[40]. KITEL, C., Introduction to Solid State Physics, J. Wiley \& Sons, 1986. 
[41].BRECHT, A.; GAUGLITZ, G., Recent Developments in Optical Transducers for Chemical or Biochemical Applications, Sensor. Actuat. B-Chem. 38, 1, (1997).

[42]. JENKINS, F. A.; WHITE, H. E, Fundamentals of Optics, Mc. Graw-Hill, 3-ed, cap. 24, 1957.

[43]. CARVALHO, J. P.; ROMERO, R.; MELO, M., Optical Fiber Communications: Recent Contributions in Photonic Device Technology, Fiber Integrated Opt. 24, 371, (2005). 


\section{Apêndice A: Etapas de processo em microeletrônica}

As técnicas de deposição de filmes finos são largamente utilizadas em tecnologia MOEMS para a fabricação de monocamadas e multicamadas.

Em óptica integrada, elas são úteis para confeccionar as camadas de isolação, guiamento e cobertura que compõem um guia óptico.

Considerando esses aspectos, é importante conhecer os processos físicos e químicos envolvidos nesta técnica, bem como suas diferentes diversidades, vantagens e desvantagens.

No processo de deposição, os filmes são formados pela união de átomos ou moléculas de um vapor sobre o substrato. Este processo se inicia pela formação de núcleos, que se espalham aleatoriamente sobre a superfície do substrato resultando numa adsorção química superficial. Quando os núcleos entram em contato uns com os outros ocorre a coalescência que resulta em estruturas maiores. O processo continua formando canais e buracos de substrato exposto, preenchidos com novos núcleos até a formação de um filme contínuo [29].

Os processos envolvidos na deposição de um filme podem ser físicos (PVD) ou químicos (CVD) [30]. A seguir, esses processos serão destacados e analisados de acordo com suas propriedades particulares.

\section{A.1 Deposição química (CVD)}

Neste processo uma ou mais espécies de gases reativos reagem na superfície do substrato, formando uma camada de filme fino sobre a mesma. A superfície do substrato deve ser aquecida a uma determinada temperatura, para favorecer a reação e a deposição do filme [29].

A energia necessária para a reação provém de diferentes fontes como calor e fótons, No entanto a energia térmica é a mais utilizada.

Os reatores CVD mais utilizados são o de pressão atmosférica (APCVD), baixa pressão (LPCVD), assistidos por plasma (PECVD) e com plasma remoto (RPECVD). A Tabela 3 sumariza as vantagens, desvantagens e principais aplicações desses reatores [29]: 
Tabela 3: Vantagens, desvantagens e aplicações de reatores CVD.

\begin{tabular}{|c|c|c|c|c|}
\hline REATOR & APCVD & LPCVD & PECVD & RPECVD \\
\hline VANTAGENS & $\begin{array}{l}\text { Simples, alta } \\
\text { taxa de } \\
\text { deposição e } \\
\text { baixa } \\
\text { temperatura. }\end{array}$ & $\begin{array}{l}\text { Excelente } \\
\text { uniformidade e } \\
\text { pureza, cobertura } \\
\text { de degrau } \\
\text { conforme. }\end{array}$ & $\begin{array}{c}\text { Baixa } \\
\text { temperatura, alta } \\
\text { taxa de deposição, } \\
\text { boa cobertura de } \\
\text { degrau. }\end{array}$ & $\begin{array}{c}\text { Baixa temperatura, boa cobertura } \\
\text { de degrau, não há radiação sobre } \\
\text { o substrato pelo plasma. }\end{array}$ \\
\hline DESVANTAGENS & $\begin{array}{l}\text { Cobertura de } \\
\text { degrau ruim e } \\
\text { contaminação } \\
\text { por partículas. }\end{array}$ & $\begin{array}{l}\text { Alta temperatura e } \\
\text { baixa taxa de } \\
\text { deposição. }\end{array}$ & $\begin{array}{l}\text { Contaminação } \\
\text { química, como } \\
\mathrm{H}_{2} \text {, e por } \\
\text { partículas. }\end{array}$ & $\begin{array}{l}\text { Alto custo do equipamento, baixa } \\
\text { taxa de deposição. }\end{array}$ \\
\hline APLICAÇÕES & $\begin{array}{l}\text { Óxidos de } \\
\text { baixa } \\
\text { temperatura, } \\
\text { dopados ou } \\
\text { não. }\end{array}$ & $\begin{array}{l}\text { Óxidos de alta } \\
\text { temperatura, } \\
\text { dopados ou não, } \\
\text { nitreto de silício, } \\
\text { polisilício e } \\
\text { tungstênio }\end{array}$ & $\begin{array}{l}\text { Deposição de } \\
\text { dielétricos sobre } \\
\text { metais em baixa } \\
\text { temperatura, } \\
\text { nitreto de silício } \\
\text { para passivação. }\end{array}$ & $\begin{array}{c}\text { Deposição de dielétricos sobre } \\
\text { metais em baixa temperatura, } \\
\text { nitreto de silício para passivação } \\
\text { e dielétricos de porta em } \\
\text { estruturas MOS. }\end{array}$ \\
\hline
\end{tabular}

\section{A.2 Deposição física (PVD)}

Nesta técnica, um material é transferido de uma fonte sólida, num ambiente de baixa pressão, para um substrato.

A deposição pode ser realizada pela evaporação em alto vácuo do material fonte do filme (evaporação térmica), por um feixe de elétrons com alta energia que bombardeia o material a ser evaporado (evaporação por feixe de elétrons) ou ainda pelo mecanismo de ejeção de material de uma superfície (alvo) pelo bombardeamento de partículas com alta energia (Sputtering).

A Tabela 4 diferencia esses processos quanto as suas vantagens, desvantagens e aplicações [29]: 
Tabela 4: Vantagens, desvantagens e aplicações dos processos de deposição física.

\begin{tabular}{|c|c|c|c|}
\hline MÉTODOS & $\begin{array}{c}\text { EVAPORAÇÃO } \\
\text { POR FEIXE DE } \\
\text { ELÉTRONS }\end{array}$ & $\begin{array}{c}\text { EVAPORAÇÃO } \\
\text { TÉRMICA }\end{array}$ & SPUTTERING \\
\hline VANTAGENS & $\begin{array}{c}\text { Filmes mais } \\
\text { uniformes, melhor } \\
\text { cobertura de degrau, } \\
\text { melhor controle de } \\
\text { processo. }\end{array}$ & $\begin{array}{c}\text { Causa menos danos à } \\
\text { superfície, menor } \\
\text { contaminação (alto vácuo). }\end{array}$ & $\begin{array}{c}\text { Independe do substrato e do material a } \\
\text { ser depositado, baixa toxidade dos gases } \\
\text { contaminação do meio ambiente, alta } \\
\text { produtividade, rendimento e } \\
\text { reprodutibilidade. }\end{array}$ \\
\hline DESVANTAGENS & $\begin{array}{c}\text { Baixa taxa de } \\
\text { elevosição, custo } \\
\text { de raios-X. }\end{array}$ & $\begin{array}{c}\text { Difícil controle da } \\
\text { composição de ligas, } \\
\text { uniformidade depende da } \\
\text { geometria do reator, } \\
\text { impossível a limpeza "in } \\
\text { situ". }\end{array}$ & $\begin{array}{c}\text { Alto custo dos equipamentos e sua } \\
\text { respectiva manutenção e alta } \\
\text { especialização. }\end{array}$ \\
\hline APLICAÇÕES & Filmes metálicos. & Filmes metálicos. & $\begin{array}{c}\text { Filmes metálicos, dielétricos, ligas } \\
\text { metálicas e ligas compostas. }\end{array}$ \\
\hline
\end{tabular}

Em óptica integrada, é imprescindível que os filmes utilizados tenham alta homogeneidade e menor quantidade de defeitos possível [30], [31]. A baixa homogeneidade acarreta uma alta perda óptica por mecanismos de espalhamento e a presença de defeitos induz uma mudança do índice de refração local ou uma absorção de luz pela banda proibida para fótons dentro do filme. Todos esses fatores devem ser levados em consideração no momento da escolha dos processos de fabricação [30].

\section{A.3 Técnicas de corrosão}

As técnicas de corrosão, utilizadas para remover um material seletivamente de um substrato, vem sendo largamente aplicadas na fabricação de microssensores, atuadores e estruturas eletroópticas [32]. Os métodos de corrosão utilizados em larga escala são a corrosão seca e a corrosão úmida [29].

Num processo de corrosão, ocorre a chegada dos reagentes à superfície da amostra, reação destes reagentes na superfície e remoção dos produtos da superfície.

Um processo de corrosão pode ser feito via úmida (anisotrópica ou isotrópica) ou via seca (isotrópica).

A corrosão úmida geralmente é feita por soluções ácidas ou básicas. Com esta, podemos ter uma corrosão seletiva de silício em alguns tipos de soluções. Ela possui a vantagem de ser mais 
rápida que a seca e ter uma taxa de corrosão maior. As corrosões úmidas anisotrópicas podem ter uma taxa aproximadamente $1 \mu \mathrm{m} / \mathrm{min}$ [12], [33].

\section{A.3.1 Corrosão anisotrópica em substratos de silício}

Neste tipo de corrosão o cristal é corroído com taxas diferentes nas várias dimensões atômicas. Por exemplo, com uma solução de $\mathrm{KOH} 30 \%$ a $60^{\circ} \mathrm{C}$ o silício <100> é corroído a uma taxa de $24,4 \mu \mathrm{m} / \mathrm{h}$. Já a orientação $<110>$ é corroída a uma taxa de $37 \mu \mathrm{m} / \mathrm{h}$ [12].

Devido a forte dependência da taxa de corrosão com a orientação cristalográfica, uma grande variedade de estruturas podem ser fabricadas de uma maneira altamente controlada e reprodutível. Campos importantes de aplicação incluem a fabricação de sensores, atuadores e componentes micro-ópticos [34] como sensores de pressão [34], acelerômetros [15], sensores de fluxo e conectores para guias ópticos [35], [36]. Geralmente, as soluções aquosas de corrosão anisotrópica são alcalinas, onde o componente de corrosão pode ser orgânico ou inorgânico. A solução química mais utilizada devido ao baixo custo para corrosão anisotrópica é o KOH diluído em água. Em altas concentrações de $\mathrm{KOH}$ e temperaturas da ordem de $60-85^{\circ} \mathrm{C}$, após a corrosão, podemos obter superfícies uniformes e brilhantes.

Em soluções alcalinas, há uma limitação da corrosão na lâmina (100),cujos planos de interseção (111) são corroídos a uma taxa menor que em outros planos [7].

Esse fenômeno ocorre devido a uma maior densidade de átomos, que faz ter uma maior taxa de oxidação nestes planos. A oxidação ocorre devido à liberação de radicais $\mathrm{OH}^{-}$nas soluções alcalinas. Já nos planos (111) e (110) a taxa de oxidação é menor, pois a distância entre os átomos é maior.

As etapas da corrosão podem ser observadas pelas seguintes reações [7]:

$$
\begin{aligned}
\mathrm{Si}+2 \mathrm{OH} & \rightleftarrows(\mathrm{OH})^{+2}+2 \mathrm{e}^{-} \\
\mathrm{Si}(\mathrm{OH})^{+2} 2+2 \mathrm{OH} & \rightleftarrows \mathrm{Si}(\mathrm{OH})_{4}+2 \mathrm{e}^{-} \\
\mathrm{Si}(\mathrm{OH})_{4}+4 \mathrm{e}^{-}+4 \mathrm{H} 2 \mathrm{O} & \rightleftarrows \mathrm{Si}(\mathrm{OH})^{-2}{ }^{2}+2 \mathrm{H}_{2}
\end{aligned}
$$

Analisando as etapas descritas acima, percebe-se que as reações que causam a oxidação dos planos cristalinos consomem água e liberam hidrogênio. Este é um fator que deve ser considerado 
na hora de inspecionar visualmente o processo, pois é esperado que se soltem bolhas do substrato durante a corrosão.

A cristalografia do silício será discutida a seguir e terá utilidade para explicar as formas que podem tomar o substrato de silício ao ser submetido a soluções de corrosão química.

O silício cristalino, como a maioria dos elementos da coluna IV, possui uma estrutura cúbica de face centrada (fcc) do tipo diamante [36]. A estrutura do tipo diamante pode ser visualizada como duas estruturas fcc apoiadas sobre a diagonal (111) do cubo, separadas espacialmente em 1/4 da distância da diagonal. No caso particular do silício, o parâmetro de rede é 0,54 nm [36]. A rede cristalina do silício pode ser visualizada na Figura 21:

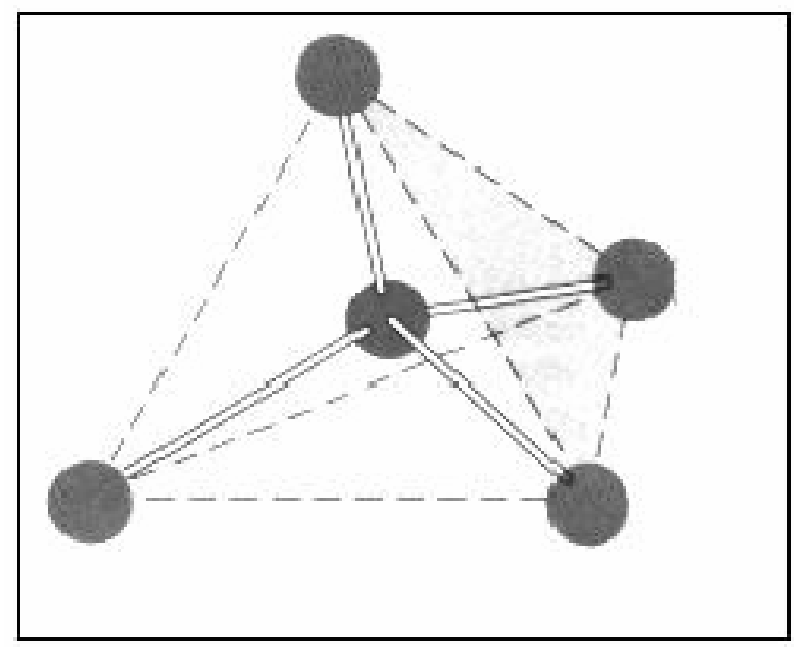

Figura 21: Rede cristalina do silício.

Sendo as paredes do plano (111) inclinadas, após algum tempo de corrosão elas se encontram em um ângulo que pode ser calculado pelo produto escalar dos índices de Miller [36] dos planos (100) e (111). Este leva a um arco cujo cosseno fornece um valor de 54,7º ângulo notável para aplicações em óptica integrada [26].

Dependendo da largura da estrutura, definida pela máscara litográfica, podemos obter maior profundidade na corrosão. Para estruturas mais largas, os planos (111) das paredes corroídas não se interceptam e o resultado é um perfil trapezoidal [12] como podemos ver na Figura 22 

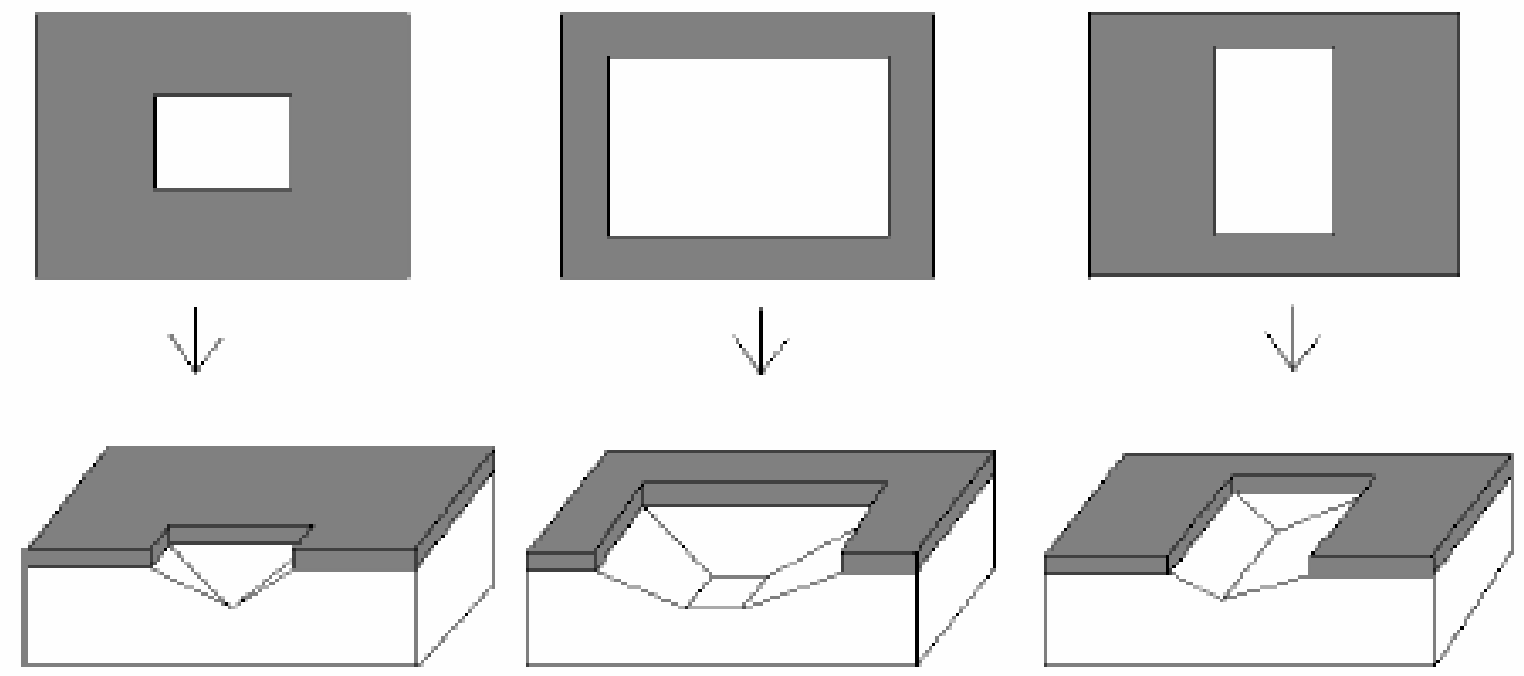

Figura 22: Perfis de corrosão anisotrópica para silício $<100>$.

A taxa de corrosão depende também da temperatura do processamento do substrato [37].

Geralmente, para fazer uma corrosão úmida de silício, utiliza-se uma solução contendo KOH.

Além do $\mathrm{KOH}$ utilizado em corrosões anisotrópicas, também é possível usar uma base orgânica, como o TMAH (tetrametil hidróxido de amônia). A taxa de corrosão é $1 \mu \mathrm{m} / \mathrm{min}$ para o TMAH (a $90^{\circ} \mathrm{C}$ ) enquanto que para o $\mathrm{KOH}\left(\mathrm{a} 85^{\circ} \mathrm{C}\right)$ é de $1,4 \mu \mathrm{m} / \mathrm{min}$ [12]. Porém, o TMAH é livre de contaminação de potássio e gera uma rugosidade menor do que o $\mathrm{KOH}$ [29]. O processo deste trabalho não sofre influência significativa sob cargas móveis. Sendo o KOH mais barato e com boa disponibilidade, optamos por utilizá-lo.

A taxa de corrosão do silício (100) a uma temperatura de $60^{\circ} \mathrm{C}$ por uma solução de $\mathrm{KOH} 27 \%$ foi estimada por Seidel et al [7] através da modelagem de Arrhenius. Ela está em torno de $30 \mu \mathrm{m} / \mathrm{h}$.

\section{A.3.2 Corrosão isotrópica em substratos de silício}

Neste processo, o cristal é corroído igualmente nas várias direções atômicas.

As soluções químicas de corrosão isotrópica tendem a remover o material uniformemente em todas as direções e são limitadas pelo transporte de massa das espécies químicas até a superfície do cristal. As taxas de reação na superfície são tão grandes que variações na estrutura atômica 
não alteram a velocidade de reação relativa ao transporte químico [29]. Um perfil típico de estrutura obtida está mostrado na Figura 23:

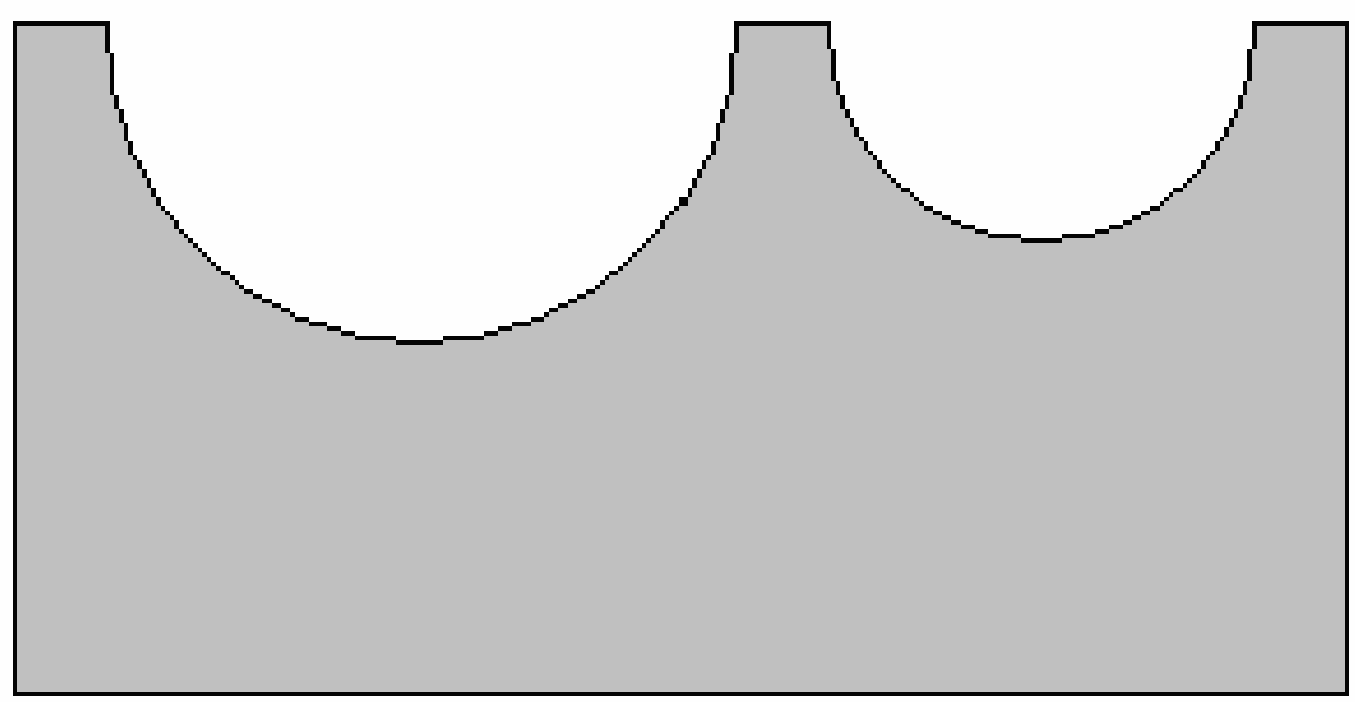

Figura 23: Perfil de corrosão isotrópico.

Estruturas em U são fabricadas utilizando-se corrosões isotrópicas de um substrato. Este perfil de corrosão pode ser obtido através de soluções químicas ou via plasma [30].Geralmente, para se fazer corrosão isotrópica de silício por via úmida, utiliza-se soluções baseadas em misturas de $\mathrm{HF}$ e $\mathrm{HNO}_{3}$ [31], popularmente conhecidas como HNA. A taxa de corrosão do substrato de silício, neste caso, varia com a proporção dos reagentes utilizados.

Nesta composição, o $\mathrm{HNO}_{3}$ promove a oxidação do silício enquanto os íons $\mathrm{F}^{-}$do $\mathrm{HF}$ são responsáveis pela formação de um composto solúvel no silício $\left(\mathrm{H}_{2} \mathrm{SiF}_{6}\right) \cdot \mathrm{O} \mathrm{H}_{3} \mathrm{COOH}$, que tem menor polaridade que a água devido a sua baixa constante dielétrica no estado líquido, ajuda a prevenir a dissociação do $\mathrm{HNO}_{3}$ em $\mathrm{NO}_{3}{ }^{-}$ou $\mathrm{NO}_{2}{ }^{-}$, permitindo a formação de espécies diretamente responsáveis pela oxidação do silício.

Utilizando uma solução contendo $900 \mathrm{ml}$ de $\mathrm{HNO}_{3}, 95 \mathrm{ml}$ de $\mathrm{HF}, 5 \mathrm{ml}$ de $\mathrm{H}_{3} \mathrm{COOH}$ e $14 \mathrm{~g}$ de $\mathrm{NaClO}_{2}$, Williams et al [12] obtiveram uma taxa de corrosão para o silício da ordem de 15 $\mu \mathrm{m} / \mathrm{min}[12]$.

Wolf et al [29] reportam a reação geral como sendo:

$$
18 \mathrm{HF}+4 \mathrm{HNO}_{3}+3 \mathrm{Si} \rightarrow 3 \mathrm{H}_{2} \mathrm{SiF}_{6}+4 \mathrm{NO}_{(\mathrm{g})}+8 \mathrm{H}_{2} \mathrm{O}
$$


Esse mecanismo ocorre basicamente devido aos seguintes eventos:

- Injeção de lacunas no silício para formar $\mathrm{Si}^{2+} \mathrm{ou} \mathrm{Si}^{+}$.

- Ligamento dos grupos $\mathrm{OH}^{-}$ao $\mathrm{Si}^{2+}$ para formar $\mathrm{Si}(\mathrm{OH})_{2}{ }^{2+}$.

- Reação do $\mathrm{SiO}_{2}$ com o agente complexante em solução $\left(\mathrm{H}_{2} \mathrm{SiF}_{6}\right)$.

- Dissolução dos produtos da reação na solução.

\section{A.3.3 Corrosão por plasma em substratos de silício.}

A técnica de corrosão por plasma é uma boa alternativa para os processos químicos utilizados em microeletrônica. O aumento nas aplicações dos processos utilizando plasma ocorreu principalmente devido a redução das dimensões dos dispositivos eletrônicos, pois as técnicas convencionais dificultam a obtenção destes [29].

Dentre algumas das principais aplicações da tecnologia de corrosão via plasma, podemos destacar o escavamento de trincheiras que têm utilidade tanto na tecnologia MOS e CMOS [30] quanto em aplicações no ramo da óptica integrada [2].

A corrosão via plasma apresenta muitas vantagens. Podemos citar a baixa toxidade dos gases utilizados, baixo consumo de gases e contaminação do meio ambiente, alta produtividade, rendimento e reprodutibilidade de processos [33]. Além disso, este tipo de corrosão fornece um perfil que independe da orientação cristalográfica do substrato. Porém, a morfologia do substrato pode sofrer danos devido ao bombardeamento físico que geralmente predomina no processo [31].

Dentre os principais gases utilizados para o processo de corrosão por plasma, podemos citar o $\mathrm{SF}_{6}$, vapor de $\mathrm{HF}$ e $\mathrm{O}_{2}[31]$.

Basicamente, o processo de corrosão por plasma é obtido pelos seguintes mecanismos:

- Introdução do gás no reator.

- Geração das espécies reativas por plasma.

- Difusão dessas espécies para a superfície do substrato e adsorção.

- Difusão superficial para reação com o filme.

- Dessorção dos produtos da reação da superfície.

- Exaustão do gás não reagido e produtos da reação [29]. 


\section{A.4 Processo litográfico}

Na fabricação de circuitos integrados, é o processo de transferência de padrões geométricos de uma máscara para a superfície de um substrato. Este processo determina o tamanho mínimo dos padrões geométricos que serão transferidos para a lâmina, sendo este o principal fator limitante na compactação dos circuitos integrados [29].

O processo litográfico deve ser feito na seguinte ordem: limpeza de um substrato, desidratação, aplicação de um promotor de aderência, aplicação de um fotorresiste, pré cura, exposição à luz ultravioleta, revelação, cura, corrosão do filme e remoção do fotorresiste. Após a cura do fotorresiste deve ser realizada a corrosão do material não protegido para a conclusão do processo [29].

\section{A.5 Oxidação térmica}

A oxidação térmica do silício constitui um dos processos fundamentais da tecnologia de fabricação de circuitos integrados. $\mathrm{O} \mathrm{SiO}_{2}$ é muito estável e possui aplicações muito importantes para a microeletrônica. Ele é utilizado como máscara para definição das áreas de difusão ou implantação de dopantes na lâmina. Também serve como isolante elétrico entre componentes e interconexões, podendo ser utilizado como filme protetor (passivante) e é extremamente utilizado como dielétrico nos dispositivos com estrutura MOS.

As espécies oxidantes utilizadas são: oxigênio (oxidação seca) e vapor d'água (oxidação úmida). A reação química que descreve a oxidação térmica do silício é a seguinte [29]:

$$
\mathrm{Si}+2 \mathrm{H}_{2} \mathrm{O} \rightarrow \mathrm{SiO}_{2}+2 \mathrm{H}_{2}
$$

A reação de oxidação ocorre na interface $\mathrm{Si} / \mathrm{SiO}_{2}$. Conseqüentemente, como o óxido de silício cresce, o silício da lâmina é consumido e, portanto, a interface $\mathrm{Si} / \mathrm{SiO}_{2}$ muda de posição. Baseado nas densidades relativas e massas moleculares do silício e do óxido de silício é obtido que a quantidade de silício consumido corresponde a $44 \%$ da espessura final do óxido, como mostra a Figura 24.
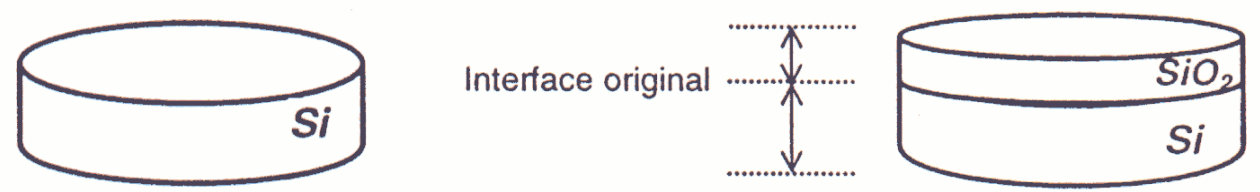

Figura 24: Oxidação térmica do silício. 
Para se crescer um filme de $\mathrm{SiO}_{2}$ com $1 \mu \mathrm{m}$ de espessura, por exemplo, ocorre um consumo de $0,46 \mu \mathrm{m}$ de silício [38].

Ao observar a cinética de oxidação do silício, verifica-se a existência de leis que determinam o crescimento do óxido. Elas são: lei de crescimento linear e lei de crescimento parabólico. A lei de crescimento linear, ocorre no início do crescimento do óxido, onde a reação é um fator limitante, ou seja, a espécie oxidante chega a superfície óxido/silício em grandes quantidades, porém a taxa de oxidação é controlada pela taxa constante de reação. Neste caso, o crescimento independe da difusão e está relacionado com a quebra de ligações na interface óxido/silício e com a orientação cristalográfica de silício. Já a lei de crescimento parabólico, determina que o crescimento é limitado pela difusão, ou seja, o fluxo de espécies oxidante através do óxido é muito pequeno comparado com o fluxo associado com a reação na interface óxido/silício [29].

A qualidade do óxido de silício depende fortemente do método utilizado para seu crescimento $[7]$.

Algumas literaturas que trabalham com guias para espectros UV, como, por exemplo, a ref. [38], atribuem as atenuações obtidas à presença de radicais hidroxila, típicos de um óxido úmido [31].

Esses radicais introduzem defeitos que podem ocasionar um espalhamento da luz pela mudança de índice de refração local através da geração de vacâncias ou uma eventual absorção de luz pela faixa proibida para fótons dentro do óxido, já que eles indicam ligações incompletas do silício.

Porém, estudos de absorbância para diferentes porosidades de óxido comprovam que esse radical não tem presença significativa para comprimentos de onda do espectro visível [38].

Propriedades importantes para aplicações em óptica integrada são a densidade e a homogeneidade do óxido obtido. A falta da primeira leva a uma absorção de luz a pelo substrato [5], e se o filme não for livre o suficiente de rugosidades pode haver uma atenuação na quantidade de luz do dispositivo [39] . 


\section{A.6 Modelamento de Arrhenius}

$$
R=R_{0} \exp \left(\frac{-E_{a}}{K T}\right)(1)
$$

Tabela 5: Parâmetros do modelamento de Arrhenius

\begin{tabular}{|l|l|}
\hline$R$ & Taxa de corrosão $(\square \mathrm{m} / \mathrm{h})$ \\
\hline$R_{0}$ & Fator pré exponencial $(\square \mathrm{m} / \mathrm{h})$ \\
\hline$E_{a}$ & Energia de ativação $(\mathrm{eV})$ \\
\hline$K$ & Constante de Boltzmann $\left(8,62 \times 10^{-15} \mathrm{eV} / \mathrm{K}\right)$ \\
\hline$T$ & Temperatura $(\mathrm{K})$ \\
\hline
\end{tabular}

A taxa de crescimento de $\mathrm{Ni}_{2} \mathrm{Si}$ é obtida utilizando-se $\mathrm{R}_{\mathrm{o}}=10^{3}$ e $\mathrm{E}_{\mathrm{a}}=1,4 \mathrm{eV}$.

A taxa de corrosão do $\mathrm{Si}$ por $\mathrm{KOH}$ é obtida utilizando-se $\mathrm{R}=3.61 * 10^{10}$ e $\mathrm{E}_{\mathrm{a}}=0.6 \mathrm{eV}$ [7]. 


\section{Apêndice B: Equações básicas para o guiamento óptico planar}

Nesta seção são apresentadas as equações básicas para a propagação de ondas eletromagnéticas em meios dielétricos. Inicialmente, abordamos a propagação em meios dielétricos planares (unidimensional) e, em seguida, a propagação em meios dielétricos retangulares (bidimensional).

\section{B.1 Equações de Maxwell}

As equações de Maxwell descrevem a natureza ondulatória da luz e fornecem os meios matemáticos para a interpretação da propagação óptica em meios dielétricos. $\mathrm{O}$ equacionamento integral está descrito a seguir [40].

$$
\begin{aligned}
& \oint_{C} \vec{E} \bullet d \vec{l}=-\frac{\partial}{\partial t} \iint_{A} \vec{B} \bullet d \vec{S} \\
& \oint_{C} \vec{H} \bullet d \vec{l}=\iint_{A}\left(\vec{J}+\frac{\partial \vec{D}}{\partial t}\right) \bullet d \vec{S} \\
& \oiint_{A} \vec{D} \bullet d \vec{S}=Q \\
& \oiint_{A} \vec{B} \bullet d \vec{S}=0
\end{aligned}
$$

Nessas equações, $\vec{S}$ é o vetor normal à superfície de integração e a área das integrais 2 e 3 cobrem somente a área fechada pela curva $c$.

$\vec{E}$ e $\vec{H}$ são os vetores campo elétrico e magnético, respectivamente e $\vec{D}$ e $\vec{B}$ são fluxos. Tanto as amplitudes como os fluxos são de natureza vetorial.

As equações de Maxwell podem ser escritas em forma diferencial. Este formato permite uma descrição mais simples dos aspectos ondulatórios do campo eletromagnético. Com o auxílio do teorema de Gauss,

$$
\oiint_{A} \vec{F} \bullet d \vec{S}=\iiint_{V} \nabla \bullet \vec{F} d V
$$

e o teorema de Stokes, 


$$
\oint_{C} \vec{F} \bullet d \vec{l}=\iint_{A} \nabla \times \vec{F} \bullet d \vec{S}
$$

temos as seguintes expressões para as equações de Maxwell:

$$
\begin{aligned}
& \nabla \times \vec{E}=-\frac{\partial \vec{B}}{\partial t} \\
& \nabla \times \vec{H}=\vec{J}+\frac{\partial \vec{D}}{\partial t} \\
& \nabla \bullet \vec{B}=0 \\
& \nabla \bullet \vec{D}=\rho
\end{aligned}
$$

\section{B.2 Relações constitutivas}

Para construir a equação de ondas eletromagnéticas na sua forma mais geral, é necessário fazer algumas considerações sobre o meio que ocorre a propagação [40].

A polarização elétrica $\vec{P}$ constitui uma medida da resposta global sobre a propagação da luz no meio, ou seja, representa o momento dipolar elétrico resultante por unidade de volume. Como o campo no material é alterado, define-se um novo campo deslocamento $\vec{D}$, ou densidade de fluxo elétrico $\left[\mathrm{C} / \mathrm{m}^{2}\right]$, através da Equação 12:

$$
\vec{D}=\varepsilon_{0} \vec{E}+\vec{P}
$$

Nesta equação, $\vec{E}$ é o campo elétrico e $\varepsilon_{0}$ é a permissividade elétrica no vácuo $[\mathrm{F} / \mathrm{m}]$.

Para um dielétrico homogêneo, linear e isotrópico $\vec{P}$ e $\vec{E}$ têm a mesma orientação e são paralelos entre si, como mostra a Equação 13.

$$
\left(\varepsilon-\varepsilon_{0}\right) \vec{E}=\vec{P}
$$

Nesta equação, $\varepsilon$ é a permissividade elétrica no meio.

Consequentemente, $\vec{D}$ é também paralelo a $\vec{E}$ : 


$$
\vec{D}=\varepsilon \vec{E}
$$

Do mesmo modo define-se uma polarização magnética $\vec{M}$ como o momento dipolar magnético por unidade de volume [40]. Deste modo, define-se um campo auxiliar $\vec{H}$, ou intensidade do campo magnético [A/m], como descrito na Equação 15:

$$
\vec{H}=\frac{\vec{B}}{\mu_{0}}-\vec{M}
$$

Nesta equação, $\vec{B}$ é a densidade de fluxo magnético e $\mu_{0}$ é a permeabilidade magnética no vácuo $[\mathrm{H} / \mathrm{m}]$.

Para um dielétrico homogêneo, linear (não ferromagnético) e isotrópico [41] a polarização magnética é nula. Sendo assim, $\vec{B}$ e $\vec{H}$ serão paralelos e proporcionais entre si, como mostra a Equação 16:

$$
\vec{H}=\frac{\vec{B}}{\mu}
$$

onde $\mu$ é permeabilidade magnética no meio.

As Equações 14 e 16 constituem as equações constitutivas [42], que permitem relacionar as densidades de fluxo $\vec{D}$ e $\vec{B}$ com os campos $\vec{E}$ e $\vec{H}$, respectivamente.

Em um meio dielétrico, as expressões gerais para permissividade e a permeabilidade não são necessariamente de grandeza escalar. Desde que os campos são grandezas vetoriais, as relações constitutivas devem ser descritas por um tensor. A densidade de fluxo elétrico, $\vec{D}$ é propriamente descrito pela Equação 17:

$$
\vec{D}_{i}=\varepsilon_{i j} \vec{E}_{j}=\left(\sum_{i=1}^{j} \varepsilon_{i j} \vec{E}_{j}\right)
$$

onde $\varepsilon_{i j}$ é o tensor permissividade. Uma expressão similar é utilizada para relacionar o fluxo magnético $\vec{B}$ com $\vec{H}$. As componentes $\varepsilon_{i j}$ dependem das propriedades do material. Cristais com baixo grau de simetria, geralmente tem uma permitividade tensorial, ao contrário dos materiais de alta simetria cristalográfica, como $\mathrm{NaCl}$ ou silício, ou materiais amorfos como o vidro, que são isotrópicos na permitividade, ao menos que a estrutura seja submetida a um estresse. 


\section{B.3 Equação de onda}

A equação de onda pode ser derivada diretamente das equações de Maxwell [40]. Para simplificar o desenvolvimento matemático, usaremos apenas o campo elétrico $\vec{E}$ no desenvolvimento das equações, sendo que, para o campo magnético $\vec{H}$, o equacionamento é semelhante. Assim, para meios dielétricos homogêneos, lineares e isotrópicos, a amplitude do campo elétrico pode ser dada pela Equação 18:

$$
\nabla^{2} \vec{E}-\mu \varepsilon \frac{\partial^{2} \vec{E}}{\partial t^{2}}=0
$$

A amplitude de campo magnético está mostrada na Equação 19

$$
\nabla^{2} \vec{H}-\mu \varepsilon \frac{\partial^{2} \vec{H}}{\partial t^{2}}=0
$$

As Equações 20 e 21 mostram algumas das soluções para as Equações 18 e 19, em módulo:

$$
\begin{aligned}
& E=E_{0} \cos (\vec{k} \bullet \vec{r}-\omega t) \\
& H=H_{0} \cos (\vec{k} \bullet \vec{r}-\omega t)
\end{aligned}
$$

Representando essas soluções no plano complexo, poderíamos exprimí-las da forma das Equações 22 e 23:

$$
\begin{aligned}
& E=E_{0} \exp (i(\omega t-\vec{k} \bullet \vec{r})) \\
& H=H_{0} \exp (i(\omega t-\vec{k} \bullet \vec{r}))
\end{aligned}
$$

Nas Equações 22 e 23, $E_{0}$ e $H_{0}$ são, respectivamente, as amplitudes do campo elétrico e campo magnético, $\vec{k}$ é o vetor de onda $[\mathrm{rad} / \mathrm{m}], \omega$ é a frequência angular $[\mathrm{rad} / \mathrm{s}]$ e $\vec{r}$ é o vetor posição.

O vetor de onda $\vec{k}$ aponta a direção de propagação de uma onda plana e seu módulo é definido na Equação 23:

$$
|\vec{k}|=\omega \sqrt{\mu \varepsilon}=k
$$


Esta equação pode ser descrita em termos do comprimento de onda, $\lambda$ :

$$
k=2 \pi / \lambda \mathrm{g}
$$

O índice de refração de um meio é definido como sendo a razão entre a velocidade de fase da luz no vácuo $c$ e a velocidade de fase da luz no meio $V_{p}$. Em relação às propriedades do material, o índice de refração $n$ é definido como [41]:

$$
n=\frac{\sqrt{\mu \varepsilon}}{\sqrt{\mu_{0} \varepsilon_{0}}}
$$

onde o subscrito (o) indica a referência ao vácuo.

\section{B.4 Guia de onda planar}

Na Figura 25, mostramos estrutura básica de um guia óptico planar. Nesta estrutura, os índices de refração das camadas de cobertura ("clad"), guiamento (núcleo ou "core") e substrato são, respectivamente, $n_{c}, n_{f}$ e $n_{s}$. A condição necessária para que a luz seja guiada é que $n_{f}$ seja maior que $n_{c}$ e que $n_{s}$ e a espessura da camada de guiamento favoreça um ângulo de incidência, $\theta_{i}$, maior que o ângulo crítico $\theta_{c}$, para a ocorrência do fenômeno de reflexão interna total. Os perfis característicos de distribuição espacial da onda eletromagnética guiada podem ser determinados matematicamente e são chamados de modos de propagação.

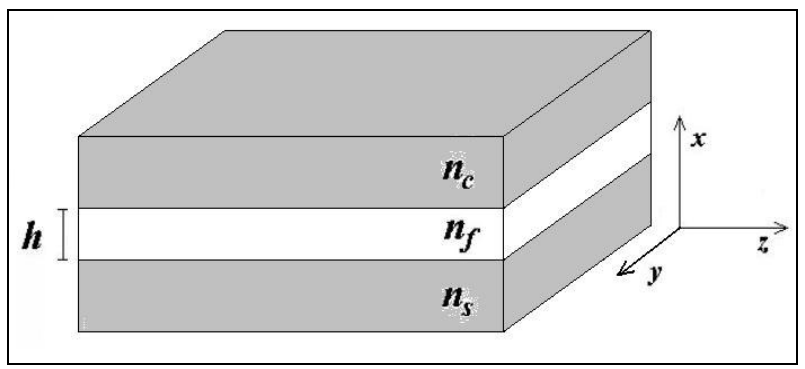

Figura 25: Guia de onda planar [35].

Os ângulos críticos para as interfaces superior e inferior são, respectivamente.

$$
\theta_{c}=\operatorname{arcsen}\left(\frac{n_{c}}{n_{f}}\right)
$$




$$
\theta_{s}=\operatorname{arcsen}\left(\frac{n_{s}}{n_{f}}\right)
$$

O guia de onda planar mostrado na Figura 25 é também chamado de guia "slab", pois uma vez que o confinamento da luz permanece somente na direção $x$ e o plano ( $y z$ ) é considerado infinito.

Devemos considerar duas possíveis polarizações do campo elétrico: elétrico transversal (TE) ou magnético transversal (TM), como é ilustrado na Figura 26, onde cruz indica o campo entrando e o círculo indica o campo saindo da página. Os casos TE e TM são distinguidos pelas características no modo, assim como suas polarizações.

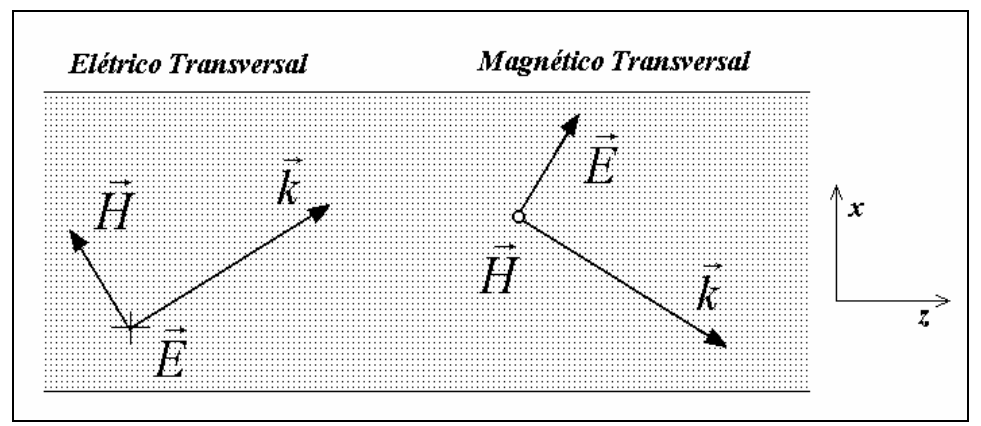

Figura 26: Configurações com o campo elétrico transversal (TE) e magnético transversal (TM).

Para o caso TE, onde o vetor campo elétrico é transversal ao plano de incidência estabelecido pela normal à interface e o vetor $\vec{k}$, assumimos que o guia de onda é excitado por uma fonte com frequência $\omega_{o}$, onde $\left|k_{o}\right|=\omega_{o} / c$. Para encontrar os modos guiados do guia óptico, devemos primeiro resolver a equação de onda para região do dielétrico e então usar as condições de contorno para relacionar tais soluções [41]. As componentes de campo elétrico para cada região podem ser escritas na forma escalar:

$$
\nabla^{2} E_{y}-k_{o}{ }^{2} n_{i}{ }^{2} \frac{\partial^{2} E_{y}}{\partial t^{2}}=0
$$

onde $n_{i}=n c, n_{f}$ ou $n_{s}$, dependendo da localização.

Podemos escrever uma solução para a Equação 29, na forma: 


$$
E_{y}(x, z)=E_{y}(x) e^{-j \beta_{i} z}(30)
$$

onde $\beta_{i}$ é uma constante de propagação ao longo da direção $z$. Relacionando esta solução com a equação 28 e notando que $d^{2} E_{y} / d y^{2}=0$, escrevemos.

$$
\frac{\partial^{2} E_{y}}{\partial x^{2}}+\left(k_{0}^{2} n_{i}^{2}-\beta^{2}\right) E_{y}=0
$$

Colocando a referência na interface inferior, a escolha do $n_{i}$ depende da posição de $x$. A solução geral, para a Equação 30, dependerá da magnitude relativa de $\beta$ em relação a $k_{0} n_{i}$. Considere o caso onde $\beta>k_{0} n_{i}$. A Equação de onda transversal (equação 32) terá uma solução geral com uma exponencial real na forma [43]:

$$
E_{y}(x)=E_{0} \exp \left( \pm \sqrt{\beta^{2}-k_{0}^{2} n_{i}^{2}} x\right)
$$

onde $E_{0}$ é a amplitude do campo em $x=0$. Para ser fisicamente razoável, nós sempre escolhemos um decaimento negativo da equação 31. Esta solução deve estar relacionada com o campo evanescente de uma reflexão interna total (RIT) da onda na interface.

No caso onde $\beta<k_{0} n_{i}$, a solução tem a forma oscilatória:

$$
E_{y}(x)=E_{0} \exp \left( \pm j \sqrt{k_{0}{ }^{2} n_{i}{ }^{2}-\beta^{2}} x\right)
$$

Então, dependendo do valor de $\beta$, a solução pode apresentar um comportamento oscilatório ou exponencial. Se $\beta<k_{0} n_{i}$, podemos definir o coeficiente de atenuação, $1 / \gamma$, como:

$$
\gamma=\sqrt{\beta^{2}-k_{0}{ }^{2} n_{i}^{2}}
$$

e descrever o campo como $E_{y}(x)=E_{0} \exp (-\not x)$. Então podemos definir o vetor de onda transversal, $\kappa$, como:

$$
\begin{gathered}
\kappa=\sqrt{k_{0}{ }^{2} n_{i}{ }^{2}-\beta^{2}}(35) \mathrm{e} \\
E_{y}(x)=E_{0} \exp ( \pm j \kappa x)
\end{gathered}
$$


Usando a Equação 34, podemos ver que $\kappa$ pode ser geometricamente relacionado com o vetor de onda total $k=k_{0} n_{f}$, no filme guiado, como mostra a Figura 27:

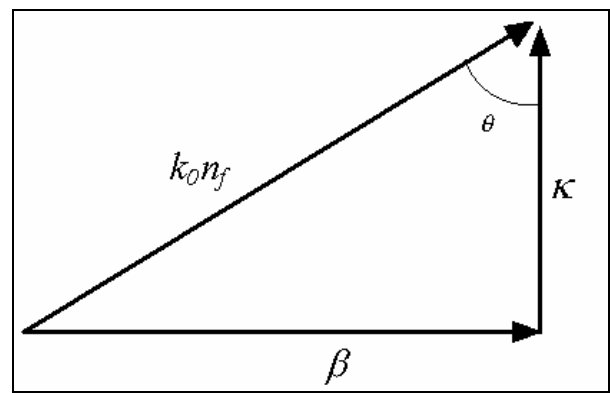

Figura 27: Diagrama do vetor de onda [4].

A relação entre o ângulo de incidência $\theta$ e as constantes de propagação ao longo de $x$ e z são:

$$
\begin{aligned}
& \kappa=k_{0} n_{f} \cos \theta \\
& \beta=k_{0} n_{f} \operatorname{sen} \theta
\end{aligned}
$$

$\beta$ e $\kappa$ são chamados de vetores de onda longitudinal e transversal, respectivamente, dentro do filme guia. Estes termos serão extensivamente empregados para caracterizar os vários tipos de modos nos guias ópticos.

\section{B.5 O vetor de onda longitudinal $\beta$}

Este vetor é usado para identificar os modos individuais e é definido como o parâmetro numérico do modo. A Figura 28 mostra a distribuição do campo elétrico transversal [35] em um guia planar para os vários valores de $\beta$, variando-se o ângulo entre $k$ e o eixo $z$ de $90^{\circ}$ a $0^{\circ}$, considerando $n_{c} \leq n_{s}$. Portanto, o valor de $\beta$, no qual é simplesmente a componente do vetor de onda em $z$, varia de 0 a $\beta_{M A X}=k$. 


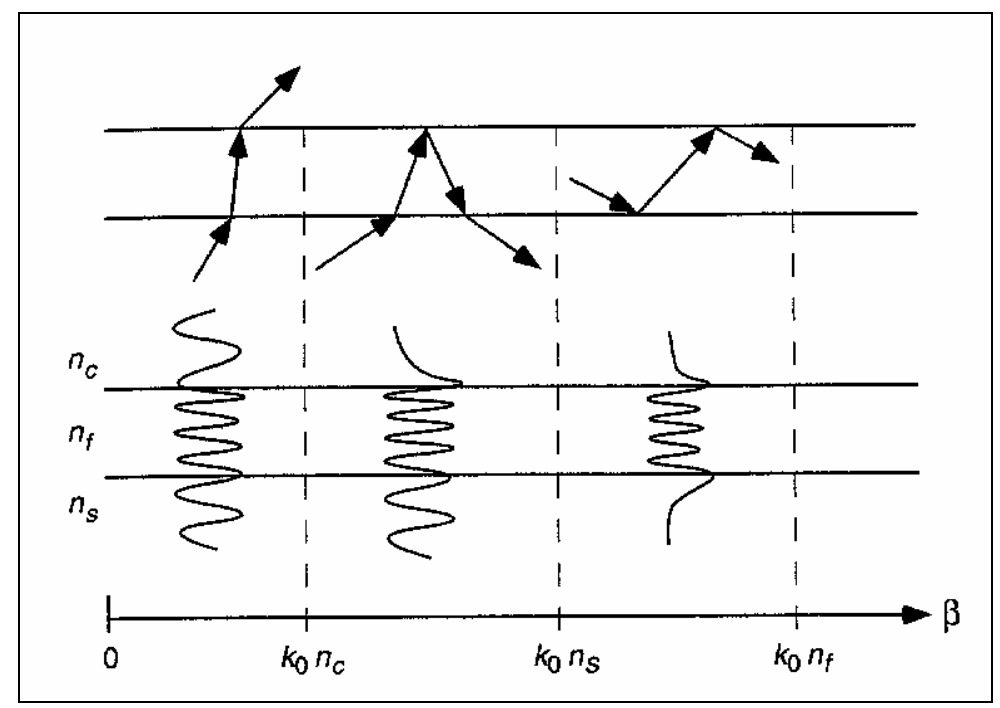

Figura 28: Distribuição do campo elétrico transversal para vários ângulos de incidência [4].

Para $\beta<k_{0} n_{c}$, as soluções da equação de onda em todas as regiões são oscilatórias, como na Equação 33 e para $\beta \approx 0$, a onda se propaga quase que perpendicularmente ao eixo $z$ do guia óptico, refratando nas interfaces dielétricas sem nenhum confinamento.

Para $k_{0} n_{c}<\beta<k_{0} n_{s}$, temos a reflexão total somente na interface superior, permanecendo um campo oscilatório no filme e no substrato.

Quando $\beta<k_{0} n_{s}$, as condições de reflexão total são satisfeitas em ambas interfaces, confinando o feixe dentro do filme e, portanto, teremos uma solução oscilatória somente na região do filme.

Para $\beta=k_{0} n_{f}$, temos o ângulo de incidência igual a $90^{\circ}$. Deste modo, a onda guiada deve satisfazer a seguinte condição [35]:

$$
k_{0} n_{s}<\beta<k_{0} n_{f}(39)
$$

\section{B.6 Equação característica dos modos}

Para encontrarmos o número de modos em um guia óptico, temos que reunir as condições vistas anteriormente e analisá-las para cada região, respeitando as condições de contorno. A equação característica para os modos TE de um guia planar pode ser escrita na forma [35]: 


$$
\tan \left(t \kappa_{f}\right)=\frac{\gamma_{c}+\gamma_{s}}{\kappa_{f}\left[1-\frac{\gamma_{c} \gamma_{c}}{\kappa_{f}^{2}}\right]}(40)
$$

onde $t$ é a espessura do filme guia.

Para o caso TM temos:

$$
\tan \left(t k_{f}\right)=\frac{\kappa_{f}\left[\frac{n_{f}{ }^{2}}{n_{s}{ }^{2}} \gamma_{s}+\frac{n_{f}{ }^{2}}{n_{c}{ }^{2}} \gamma_{c}\right]}{\kappa_{f}{ }^{2}-\frac{n_{f}{ }^{4}}{n_{c}{ }^{2} n_{s}{ }^{2}} \gamma_{s} \gamma_{c}}
$$

Estas equações transcendentais devem ser resolvidas numericamente ou graficamente. Um exemplo gráfico para uma polarização TE é colocado na Figura 29.

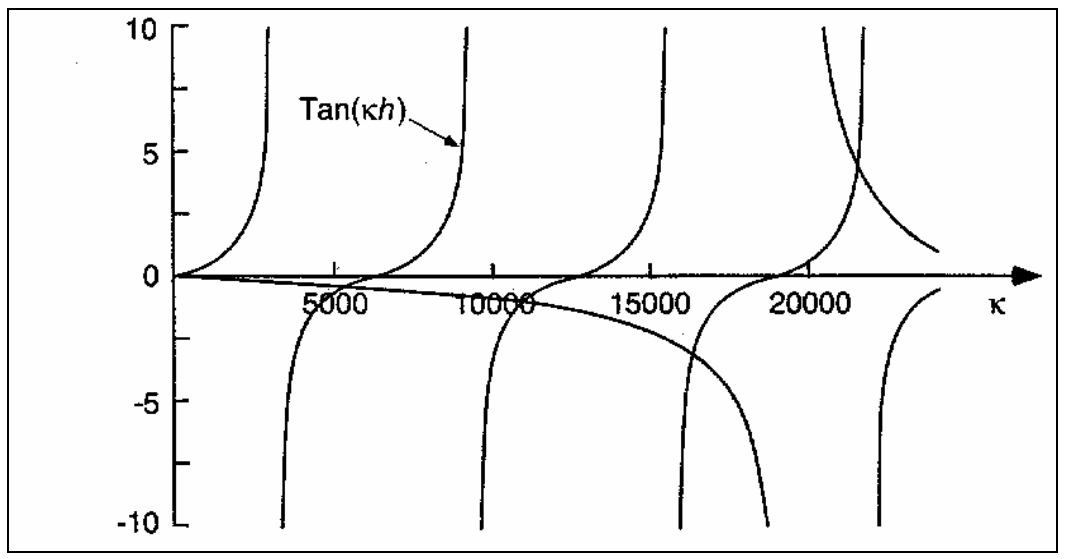

Figura 29: Solução gráfica da Equação 39, mostrando quatro valores de $\kappa$ permitidos [4]. 